Florida International University FIU Digital Commons

$12-11-1987$

\title{
An analysis of Venezuela's foreign policy during the period of the Betancourt doctrine and Calderas ideological pluralism
}

Franklin Acosta

Florida International University

DOI: $10.25148 /$ etd.FI13101522

Follow this and additional works at: https://digitalcommons.fiu.edu/etd

Part of the International and Area Studies Commons

\section{Recommended Citation}

Acosta, Franklin, "An analysis of Venezuela's foreign policy during the period of the Betancourt doctrine and Caldera's ideological pluralism" (1987). FIU Electronic Theses and Dissertations. 1102.

https://digitalcommons.fiu.edu/etd/1102 


\begin{abstract}
AN ANALYSIS OF VENEZUELA'S FOREIGN POLICY DURING THE PERIOD OF THE BETANCOURT DOCTRINE AND

CALDERA'S IDEOLOGICAL PLURALISM
\end{abstract}

by

Franklin Acosta

This thesis examines the foreign policy of Venezuela during the period of the Betancourt Doctrine (1945-1948 and 1959-1963), and Caldera's Ideological Pluralism (1969-1973). The study seeks to determine whether, and to what extent the pursuit of political and economic interests and ideology determined Venezuela's foreign policy.

Based on primary and secondary sources, this study examines political economy and ideology and how these affected the outcome of Venezuela's foreign policy.

The major finding of this thesis is that venezuelan foreign policy was a pragmatic one but it was rationalized within an ideological framework. In fact, Venezuela was most concerned in pursuing its domestic economic and political interests but these were hidden behind an ideological facade.

Professor Kenneth I. Boodhoo, Chairperson Professor Eduardo Gamarra Professor Lisandro Pérez 


\section{AN ANALYSIS OF VENEZUELA'S FOREIGN POLICY DURING THE PERIOD OF THE BETANCOURT DOCTRINE AND \\ CALDERA'S IDEOLOGICAL PLURALISM}

$$
\text { by }
$$

Franklin Acosta

A Thesis submitted in partial fulfillment of the requirements for the degree of

MASTER OF ARTS

in

INTERNATIONAL STUDIES

FLORIDA INTERNATIONAL UNIVERSITY

Thesis Committee:

Professor Kenneth I. Boodhoo, Chairperson

Professor Eduardo Gamarra

Professor Lisandro Pérez 
To Professors Kenneth I. Boodhoo, Eduardo Gamarra, Lisandro Pérez:

This thesis, having been approved in respect to form and mechanical execution, is referred to you for judgment upon its substantial merit.

\section{James A. Mau, Dean}

College of Arts and Sciences

The thesis of Franklin Acosta is approved.

Professor Kenneth I Boodhoo

Professor Edquádó Gamarra

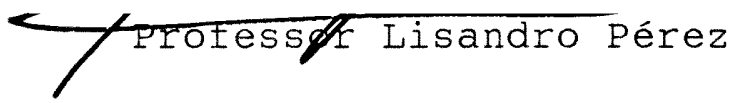

Date of Examination: December 11, 1987 
AN ANALYSIS OF VENEZUELA'S FOREIGN POLICY DURING THE PERIOD OF THE BETANCOURT DOCTRINE AND

CALDERA'S IDEOLOGICAL PLURALISM

\author{
by
}

Franklin Acosta

A Thesis submitted in partial fulfillment of the requirements for the degree of

MASTER OF ARTS

in

INTERNATIONAL STUDIES

FLORIDA INTERNATIONAL UNIVERSITY 


\section{ACKNOWLEDGMENTS}

I dedicate this work to my loving parents and to my wife whose sacrifice, support, and inspiration have been crucial in the completion of this thesis. I express also my deepest gratitude to Drs. Boodhoo, Gamarra and Pérez whose advice, guidance and recommendations not only helped improve this study but also became another source of inspiration to the writer. Finally, I am also thankful to Dr. Gerald Curtis, my friend, who unconditionally helped me with the editing and organization of the present work. 
TABLE OF CONTENTS

List of Tables $\ldots \ldots \ldots \ldots \ldots \ldots \ldots \ldots \ldots \ldots \ldots, \ldots \ldots \ldots$

INTRODUCTION $\ldots \ldots \ldots \ldots \ldots \ldots \ldots \ldots \ldots \ldots \ldots \ldots \ldots \ldots \ldots \ldots \ldots$

General Outline of Approach .............. 3 Chapters

1. THEORY AND THE ISSUE OF FOREIGN POLICY $\ldots \ldots \ldots \ldots 5$

Ideology and the Making of Foreign Policy ....... 12

Political and Economic Interests and

Foreign Policy Making ................ 20

The Foreign Policy of Venezuela: A Summary View.. 23

Approach and Methodology .............. 26

2. VENEZUELA'S FOREIGN POLICY DURING THE

PERIOD OF THE BETANCOURT DOCTRINE ......... 30

Venezuela's Foreign Policy Toward Trujillo's

Dominican Republic ..................... 33

Venezuela's Foreign Policy Toward Castro's Cuba .. 43

Venezuela's Foreign Policy Toward the

United States ......................... 51

Venezuela's Foreign Policy and the Economics and Politics of Oil: The Case of OPEC ........ 60

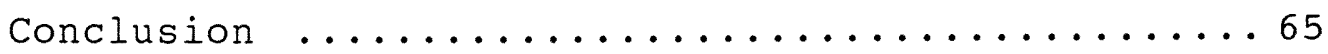

3. VENEZUELA'S FOREIGN POLICY DURING THE PERIOD OF CALDERA'S IDEOLOGICAL PLURALISM $\ldots 67$ Predominance of Dictatorial Regimes in the 


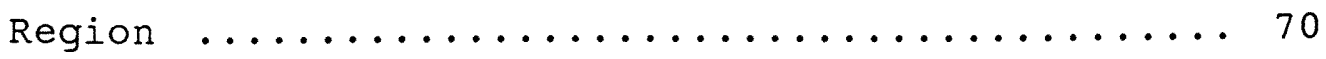

Commitment to Expand Economic Power and

Regional Influence Through Wealth .......... 74

Defense of oil Prices $\ldots \ldots \ldots \ldots \ldots \ldots \ldots \ldots$

The Andean Common Market or Andean Pact ...... 81

Conclusion $\ldots \ldots \ldots \ldots \ldots \ldots \ldots \ldots \ldots \ldots \ldots \ldots$

4. FINDINGS AND CONCLUSIONS $\ldots \ldots \ldots \ldots \ldots \ldots$

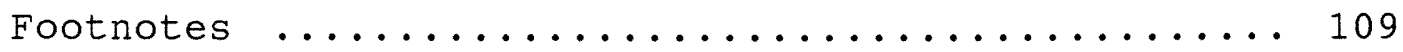

Bibliography ............................ 119

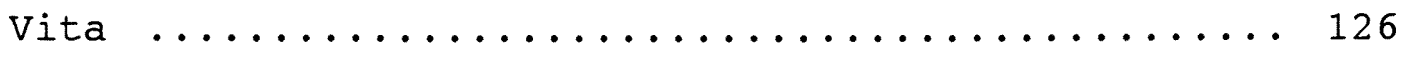


1. U.S. Direct Investment in Venezuela

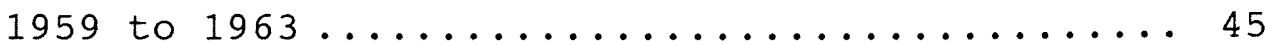

2. U.S. Government Foreign Grants and Credits

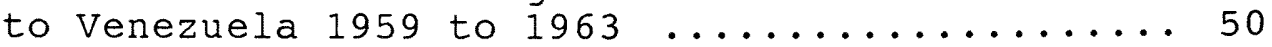

3. U.S. Direct Total Investment in Venezuela 1950 - 1956 and 1959 - $1963 \ldots \ldots \ldots \ldots \ldots \ldots$

4. U.S. Foreign Aid to Venezuela in Grants and Credits 1950 - 1956 and 1959 - $1963 \ldots \ldots \ldots$

5. The Average Rate of Growth of Per Capita Income in Latin America, 1961-1965 ........ 58

6. Impact of Oil-Price Increase on the Caldera Government's Revenues in Relation to Those of Betancourt 


\section{INTRODUCTION}

The primary purpose of this thesis is to identify whether, and to determine to what extent the pursuit of political and economic interests and ideology can affect foreign policy. The case under study will be that of Venezuela, and for purpose of analysis we will examine Venezuelan foreign policy during the period of the Betancourt Doctrine 1945-1948 and 1959-1964 (time in which Betancourt was in power), and Caldera's Ideological Pluralism 1969-1974 (time in which Caldera was in power). The study sets out to analyze the following: 1) The relationship between political and economic interests, ideology and the making of the policies of states in their international relations or relations with other states. 2) The study also seeks to determine whether, and to what extent the pursuit of political and economic interests and ideology determined Venezuela's foreign policy during the aforementioned periods.

In this study "political and economic interests" are those political and economic factors that at any given point in time can determine the choices of statesmen in formulating foreign policy; and "ideology" is those sets of values, beliefs and principles that statesmen use for guiding or justifying their actions in foreign policy. 
The content of this study relates to that realm of foreign policy theory that argues that ideology does play a role in foreign policy, but that it is relatively minor in comparison to the real interests behind it. In this introduction we tentatively hold the view that in the case of the Betancourt Doctrine, which urged non recognition of de facto or non-popularly elected governments and their expulsion from the Organization of American States; and Caldera's Ideological Pluralism, which proclaimed unity among Latin American nations regardless of ideological differences, ideology might have acted as a facade, behind which was hiding the pursuit of political and economic interests. The main task, therefore, will be to determine to what extent this holds true, and how the Betancourt Doctrine and Caldera's Ideological Pluralism fit into the general framework of foreign policy and theories thereof.

The findings of this study will help to shed more light on how nation-states behave in international relations; how domestic and external factors combine in making foreign policy; and how foreign policy can be used to satisfy domestic demands and achieve domestic goals. This study's contribution, though limited and modest, may help enhance the understanding of how and why countries behave in certain manner in their dealings with other actors on the international scene. The findings of this study may also help discern, 
with a certain degree of accuracy, the real intent behind a country's foreign policy.

\section{General Outline of Approach}

In our analysis of Venezuela's foreign policy we will divide the work into four chapters. The initial chapter develops a framework to include what has been written about foreign policy. We examine also what has been written about political economy and ideology. Chapter one also describes the methodology and approach to be used.

Chapter Two examines some of the antecedents to the Betancourt Doctrine, giving a general background of Venezuela's foreign policy prior to 1945. The study then sets out to examine Venezuela's foreign policy during the period of the Betancourt Doctrine. Here, we examine relations with Latin America, the Caribbean and the United States. It must be pointed out, however, that this chapter deals only with the periods Romulo Betancourt was in power, 1945-1948 and 1959-1964. The Perez Jimenez period, 19481958, and the Raul Leoni period, 1964-1969, will be mentioned only in passing. These periods, though significant in terms of the development of Venezuela's foreign policy, remain beyond the scope of this study.

Chapter Three deals with Venezuela's foreign policy during the period of Caldera's Ideological Pluralism (1969- 
1974). This chapter examines the most important developments which influenced the Christian Democrats' foreign policy.

Chapter Four, the concluding chapter, is the linking chapter. This chapter defines the importance of the preceding chapters, and fits chapters two and three into the conceptual framework of chapter one. This concluding chapter looks at the findings of this study and their importance. Some speculative propositions will be made about the possibility of applying the present approach to other cases. 


\section{CHAPTER I}

\section{THEORY AND THE ISSUE OF FOREIGN POLICY}

This study deals with the questions: What is foreign policy?, and, what are the most important factors that condition foreign policy? Foreign policy consists of actions taken by states in their relations with other states. These relations we call international relations. We define state here as a body of people occupying a definite territory, politically organized under one government and autonomous and independent from other governments. It is important then that we identify the state as the main actor in international relations. As John H. Herz states, "Despite the conspicuous rise of international organizations and supranational agencies ... the states remain the primary actors in international relations." 1 Contrarily to Herz's belief, Lester Pearson argues that the influence of the state in international relations is weakening. Pearson states, "The effective unit of foreign policy and strategy is no longer the nation-state, however large, but the coalition of such states ..."2

Whichever way the controversy of whether or not the state is the most important actor in international relations is settled, we must deal with reality, and reality tells that even if weakened, the state as a politically autonomous 
unit, still holds the monopoly of decision-making power in international relations. And for that matter, relations among them are still the most important in the international milieu. Evidence of this is that most definitions of foreign policy refer to the state as the major protagonist in international relations. According to Frankel, "Foreign policy consists of decisions and actions which involve to some appreciable extent relations between one state and others." 3 There is also a whole "System School" that disagrees, but for the purposes of this study we will maintain the view that the state, as defined above, is the most important actor in international relations.

Millar stresses the influence of domestic factors in affecting or determining foreign policy of states. He states,

"Foreign policy is presumably something
less than the sum of all policies which
have an effect upon a national govern-
ment's relations with other national
governments."

The reasoning behind this position is that due to technology, communication, and the high degree of sophistication of nuclear weapons distances have shortened, and today therefore there are not domestic policies so internal as to be completely isolated from the rest of the world. Domestic policies, indeed, can have such an effect on foreign countries that those policies that are exclusively "domestic", 
and that have no effect on the rest of the world, are considered "something less." The remaining of the "sum of all policies", is foreign policy.

Reynolds argues that the modern international system has become such a single unit, and so closely interrelated that action on the part of one state is constrained by the perceived domestic circumstances, as well as by the actions of other states, and how it perceives other states. 5 In a sense, he argues that foreign policy is not made in a vacuum and that it is conditioned by the domestic and international environment. The success, therefore, of foreign policy depends on how well policy-makers take into account both factors in formulating foreign policy. This study adopts the position that in analyzing foreign policy one must take into account domestic, as well as external circumstances. In this regard, our analysis of foreign policy has something in common with London's position in his book, The Making of Foreign Policy. He bases his argument on the premise that foreign and domestic politics are so inextricably linked that one cannot function without the other. Accordingly they "resemble the positive and negative components of electric current: Eliminate one and the other will not function; they produce power only when combined." 6

With this brief consideration of the question as to what "foreign policy" is, we next examine foreign policy mo- 
tivations as a corollary to the issue discussed above. Foreign policy motivation is a crucial point in the present study because knowing what foreign policy is, and where does it take place, would be pointless if we ignore what motivates foreign policy in the case of Betancourt and Caldera. According to Hans Morgenthau and the Realist school, the key concept governing the actions of statesmen in domestic and international politics is that of interests defined as power. Interests defined in terms of power, he says, "provides the link between reason trying to understand international politics and the facts to be understood."7 The premise of Morgenthau's theory is that for statesmen to be successful in the game of politics, they must equate their own personal and state's interests with power. In other words, the main task of statesmen in making foreign policy is to bring into line the desires of their nation with the power they have available for the pursuit of those desires. Foreign policy, then, must be conditioned by the pursuit of self-interests.

Morgenthau also states, "It is not enough for a government to marshal national public opinion behind its foreign policies. It must also gain the support of the public opinion of other nations ..." 8 The reasoning behind his argument is that foreign policy is not only conditioned by domestic factors, or by the domestic attractiveness of certain 
foreign policy, but by the appeal of such policy to international actors. This is, according to Morgenthau, an important point because the degree of domestic popular support that a policy enjoys, and the willingness of statesmen and the people they lead, to sacrifice anything for the pursuit of that policy they consider desirable and legitimate, is not enough. Such policy is also conditioned by the degree of support it receives from external actors. Otherwise, the policy is doomed to fail by lack of support in the international community.

There are some foreign policy theorists who would argue that in examining the most important factors that condition foreign policy one cannot ignore the role of societal factors. Rosenau, for example, states that there are domestic forces, such as the press, pressure groups, parties, and others that condition foreign policy. These forces, he says, are no less important than the external forces toward which the foreign policy is intended to be directed. ${ }^{9}$ This is a relevant point, and a crucial one in terms of our study because, as we shall examine, the Betancourt Doctrine and Caldera's Ideological pluralism did gain a great deal of strength from the support they received from private economic groups, labor unions, opposition parties and the press. 
The premises, the basic factors that must not be ignored in making foreign policy, according to London, are a nation's physical, economic and military conditions. These, he terms national attributes. "In developing his policies, no statesmen can afford to overlook certain basic factors, premises which determine the scope of his planning and his courses of action." 10 Obviously London is saying that these factors determine the limits or the range of statesmen in formulating foreign policy. Indeed, statesmen cannot go beyond their available resources, but they can convert their available resources into the main force behind their foreign policy decisions.

Frankel, on the other hand, stresses the importance of what he calls "inner element" as a conditioning factor of foreign policy that is even more important than that referred to by London. Frankel states:

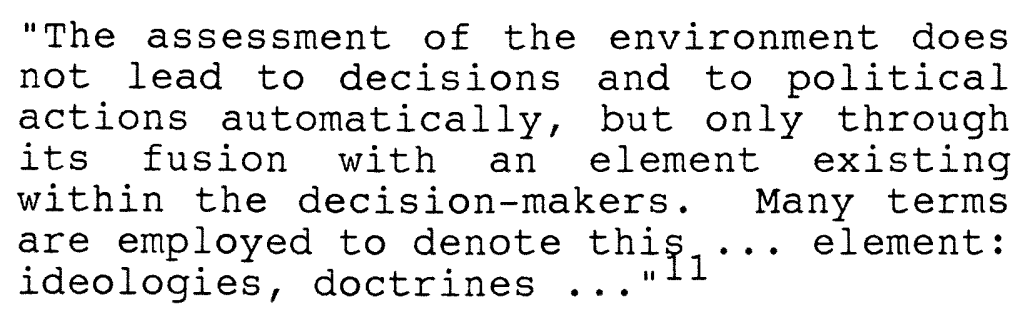

Frankel's argument is that ideologies, beliefs and values can influence statesmen in formulating their foreign policies. He uses the United States and the Soviet Union as prime examples where ideological values lead to achieving. 
important objectives in foreign policy. These values, even if they are not the primary determinants of foreign policy in general, in some issues they may well be dominant.

History and events are factors that foreign policy theorists considered to be among the most important elements that condition foreign policy. As T.B. Millar states: "The majority of foreign policy decisions... just grow. They grow out of past policies ... [and] are heavily circumscribed by the logic of events ... much of a country's foreign policy is inherited."12 To proceed further with the discussion, we could say that Millar's argument is supported by the view that events and experiences not only shape foreign policy in the sense that they help contribute to heighten or loosen economic, military or diplomatic relations, but that they also shape foreign policy in the sense of producing a distinctive type of leadership. ${ }^{3}$ This history-leadership relationship, we will find in our study when we examine how Venezuela's long history of dictatorships shaped the emergence of a new type of democratic leadership, such as that of Romulo Betancourt and Rafael Caldera.

In summary, foreign policy consists of relations between actors in the international arena, of which the state is the most important. The actions of one state in relation to others are conditioned by domestic as well as by international factors. The primary concern of all states is the 
protection and pursuit of self-interests, which means that no state will act against its own interests to preserve or further those of another. In this study then we will explore the issue of ideology as another "factor" which leads to foreign policy making.

Ideology and the Making of Foreign Policy

Our purpose in the present study is to determine the link, if any, which exists between ideology and political behavior, and to what extent ideology makes a difference in political behavior or in political action.

From Derek Heater's Contemporary Political Ideas we draw the following:

"[Ideologies are] articulated sets of ideals, ends, and purposes, which help ... to interpret the past, explain the presenty and offer a vision for the fu-

According to Heater ideologies would give people a sense of orientation. A sense of knowing where they come from, where. they are, and where they are going.

Marx on the other hand would argue that ideologies only exist to maintain the ends and purposes of the dominant classes.

"The real forces driving an ideologist remain unconscious: patriotic feeling, class interests ... Ideologists see that their class is always trying to pile larger burdens of labor on the toiling 
masses. The social order seems unfair, it." 15 the ideologists want to justify

For Marx ideology is false consciousness, mere thought that is used to keep the status quo, and guide society in the direction of the interests of the ruling class. As Drucker states: "... an ideology ... is the intellectual tool of the opposition class."16

Regarding the idea that ideology is false consciousness, Plamenatz believes that "by false consciousness Marx appears to have meant a set of mistaken beliefs ... Bourgeois ideas about the state are, so Marx believed, an example of false consciousness."17 In general, Marx spoke of ideology as if its primary function were to promote class interests. To him the ideologies of the dominant class promote and protect its interests by justifying the established order.

Speaking of ideologies Karl Mannhein argues that ideologies are used not to show the real nature of a situation, but that "they are regarded as more or less conscious disguises ... the true recognition of which would not be in accord with the interests."18 The study of ideology, according to Mannhein, "has made its task to unmask the more or less conscious deceptions ... of human interests ... particularly those of political parties." 19 
In Robert D. Putnam's The Beliefs of Politicians we find several definitions of ideology that could be useful in terms of the present discussion. At this point we must remember that we are trying to explain: to what extent does ideology explain anything about the nature of foreign policy? According to Putnam, then, a political actor may be said to be ideologically inclined when he is: "1) Guided by a belief system that is ... emotionally charged. 2) Hostile and intolerant toward political opponents ... 3) Guided by a comprehensive ... organized belief system."20 This set of characteristics obviously speaks about what an ideologically inclined politician should be. However, as it refers to ideology as belief, it fails to account for the pragmatic politician, who though not ideologically oriented, still is belief-oriented. This is precisely expressed by sartori who points out that beliefs are not necessarily ideologies. He makes the difference between "ideological" and "pragmatic" politicians. "By definition, then, not all political belief systems are ideological ... pragmatism is also a state of belief system." Then he goes on to state emphatically: "the presence of beliefs does not suffice to qualify the ideological nature of such beliefs: the pragmatic actor also is belief oriented." 21

Regarding the question, how much does ideology affect foreign policy, some theorists argue that ideologies are 
used as a facade to justify the pursuit of the real interests hiding behind it. For example, London states:

"Many decision makers and political analysts seem to believe that ideology is used to justify policies and açtions instead of being shaped by it."

According to London, in analyzing foreign policy one should be aware of the fallacy of equating foreign policy with the ideological convictions of those who formulate it. Moreover, in the analysis of foreign policy, according to London, ideology should be considered the means rather than the end. In other words, ideology is a resource to achieve objectives.

This brings the discussion to Morgenthau's views on ideology. For him ideologies are no more than disguises to hide the pursuit of self-interests and power. "It is a characteristic aspect of all politics", he suggests, "domestic as well as international, that frequently its basic manifestations do not appear as what they actually are manifestations of a struggle for power."23 According to Morgenthau, ideologies are used by statesmen to unite the masses behind their efforts, and legitimize their policies.

Morgenthau also declares that: "the actor on the political scene cannot help 'playing an act' by concealing the true nature of his political actions behind the mask of a political ideology."24 Morgenthau's position obviously re- 
lates to that of Marx in the sense that they regard ideology as means to seeking, keeping and justifying power.

The discussion comes to the point where we must briefly examine the second dimension of ideology. In this study we seek to demonstrate that the Betancourt Doctrine and Caldera's Ideological Pluralism were linked to AD (Acción Democrática) and COPEI's (Comité de Organización Política Electoral Independiente) ideological tenets. These two were Romulo Betancourt and Rafael Caldera's parties. We now proceed to examine some basic doctrine of the Social Democrats (AD) and the Christian Democrats (COPEI).

We will refer to some basic tenets of Latin American social democrats in the "APRISTA" sense, and in order to do it we must keep in mind the close relationship between Latin American social democracy and Latin American populism mainly because as in the case of APRA and AD, both, social democracy and populism, can be used to define their ideological stands. APRA, for example, is regarded by some the oldest social democrat party in Latin America, but we must also remember that APRA is a populist party. AD also was a populist party between 1945-1948 but it later moved to a more moderate stand.

Latin American populism, as viewed by Steven Ellner, displays several fundamental characteristics: commitment to radical reforms and electoral expansion, nationalism, and 
advocacy of a multi-class party. 23 These characteristics heavily marked Betancourt's AD first government between 1945-1948. However, pragmatic considerations led Betancourt's AD to adopt a more lenient stand in 1959. A stand, more in accordance with Needler's definition of Latin American social democracy, "the impulse that animates the Aprista parties might loosely be termed 'socialist' in the general sense in which Christian Democrats are referred to as Christian Socialists ... They differ clearly from the socialist parties proper, however, in being pragmatic, unbound by doctrine ... certainly not Marxists."26 In general, social democrats do not adhere to dogmas but instead to pragmatism, and they are committed to democratic and economic reforms. They believe in centralized planning and in channeling resources as a means to bringing about the economic transformation of their countries.

Christian Democrats, on the other hand, though also committed to the cause of the underprivileged, are apparently more ideologically inclined than social democrats. The essential object of Christian Democrats is to transfer the teachings of Christianity into the political realm. As stated by Louis Wasserman: "Christian socialism is the doctrine held by those who reject the elements of capitalist society and accept the program of socialism as consistent with Christian principles." 27 
Christian Democrats argue that capitalism as well as communism are exploitative in nature, one economically, the other politically. Speaking about capitalism from the West, Christian democrats say that "the system imposes upon the workers a continual 'state of misery' ... [it] violates the possibility of Christian brotherhood and replaces it with ... competition." 28 Communism, on the other hand, is repelled on philosophical grounds because of its atheist nature, but it is also rejected on ideological grounds. As a Christian Democrat's international congress declared: "[Christian Democracy] also rejects Marxists solutions which propose to replace ... the dictatorship of capital with the dictatorship of the state."29 In essence, Christian Democrats consider themselves an alternative third force, against the exploitative nature of communism and capitalism.

Pluralism is another basic tenet of Christian Democrat's doctrine. Pluralism is what brings unity where there is diversity. The concept of Pluralism harmonizes the different tendencies of men in society, pulling together their different views in order to face common necessities. As Eduardo Frei Montalva, Chile's former president (1964-1970) puts it,

"[Pluralism is an] optimistic philosophy, which believes that it is possible for men of the most distinct schools of thought and most diverse beliefs to march in common." 30 
Pluralism then is a cohesive force. It is a force in which different people, with different criteria, but with one common goal, merge with the purpose of pursuing their objectives, achieving unity in the midst of diversity.

Social justice is also one of the foremost concepts in Christian Democrats' doctrine. Social justice is that quality through which a person in society conforms his own desires, and all that is needed of him for the common good of society. 31 One of the main developments in Christian Democratic doctrine, then, came in the last three decades with the concept of international social justice, as a necessary corollary to social justice. Rafael Caldera was the one who took the task of transferring the concept of social justice to the international arena. In Caldera's own words:

"There is one social justice: the one demanding a higher duty of the strong towards the weak ... this social justice imposes what is necessary for the common good ... It tells us that ... the wealthier countries have greater 32 duties toward the poorer countries ..."32

The reasoning behind Caldera's argument is that international social justice imposes an obligation on the wealthy and developed countries of the world to help the poor and underdeveloped nations. As in domestic social justice, the achievement of the common good through unselfish consecration to improving the lot of others, is the main goal of international social justice. International social justice 
also calls for the poor nations of the world to be united under the rubric of Ideological Pluralism. With this brief consideration of the question as to how ideology relates to foreign policy making, we next examine the issue of political and economic interests as another factor which leads to foreign policy making.

Political and Economic Interests and Foreign Policy Making

There are two issues to examine here: 1) Political and economic. 2) Domestic and international. For several major reasons, issues one and two must not be separated if we want to make an accurate assessment of Venezuela's foreign policy. For instance: How could we examine Venezuela's foreign policy in terms of the oil industry without due consideration to the role of the United States, as well as domestic factors? How could we deal with Venezuela and the OPEC issue without due consideration to internal demands as well as external pressures? And finally, how could we accurately address Venezuela's problems in joining the Andean Common Market without due consideration to the opposition confronted by the government from Venezuela's private business group organizations?

Our premise then is that for countries to formulate foreign policy they have to link domestic and international politics and economics because the mutual impact between do- 
mestic and international factors cannot be ignored. Roger Tooze argues: "No process, policy, or event is unquestioningly accepted as either purely economic or political or, for that matter, as purely international or domestic."33 Roger Tooze's argument relates to that of Millar (cited above) in the sense that both consider that today there are not domestic economic and political policies so internal as to be completely isolated from the rest of the world and vice versa.

But the major problem in understanding global politics, according to Blake and Walters, has been the lack of conceptual frameworks addressing the issue of interrelatiorships between internal and international economic and political behaviors. It was not until recently that scholars began research in this direction. Blake and Walters, like Tooze and Millar, maintain that a complete understanding of global relations cannot be attained unless we establish the necessary linkages between factors:

"A complete understanding of the international political economy requires ... a systematic examination of $\ldots$ interrelationships ... between political and economic matters, between the domestic and international arena ... these various sets of interrelationships are them-
selves linked to one another." 34

Indeed, the essence of their argument is that this interconnection between domestic and external factors becomes par- 
ticularly evident in the formulating and analysis of foreign policy. In the context of the present study, the main challenge will be to determine whether, or to what extent, the Betancourt Doctrine and Caldera's Ideological Pluralism were conditioned by the interconnection mentioned by Blake and Walters.

Scholars who write within the "dependency" tradition would argue, for instance, that there is indeed a linkage between the domestic and international political economy but that it is based on inequality. Accordingly, this inequality flows from the ties established between dominant elites in the dependent and dominant countries, affecting the internal conditions of the dependent country and perpetuating inequality. As stated by Theotonio Dos Santos: "[Dependency is] a situation in which the economy of certain countries is conditioned by the development ... of another economy to which the former is subjected ..."35 According to Dos Santos' statement, we could expect that the foreign policy of a dominant power, such as the United States, will be an instrument to preserve and carry out the interests of North American corporations located in a dominated or dependent country such as Venezuela. Conversely, a dependent state's foreign policy would be expected to coincide with the interests of the ruling elites in the dominated as well as in the dominant country. 
In sum, disproportionate economic relations have brought about an unequal relationship in which the dominant country is expected to exert considerable influence in the dependent country's foreign policy. The dependent country, in turn, is expected to receive economic and/or political compensation.

From the above, we may now state that our main task will be to explain whether, and to what extent the linkage between domestic-political and economic concerns and international-political and economic concerns, determined Venezuela's foreign policy. Also, we will have to explain whether ideology played a role in the determination of the foreign policy of Venezuela, or if it was only a mean to justify the ends. Finally we must discover whether, and to what extent Venezuela's foreign policy during the period of the Betancourt Doctrine and Caldera's Ideological Pluralism, was determined by U.S.'S economic domination. In order to deal with the aforementioned questions we will need to explore some of the literature written about Venezuelan foreign policy.

The Foreign Policy of Venezuela: A Summary View

Venezuelan foreign policy could be described as a combination of idealism, pragmatism and the indefatigable search for development. No study of contemporary Venezuelan 
foreign policy could exclude the decisive role that oil has played in shaping foreign and domestic policies. Arturo $U$. Pietri describes Venezuela as being heavily conditioned by the politics and economics of oil:

"Oil is the fundamental and basic fact of the Venezuelan destiny ... Everything else loses significance ... All issues by oil." ${ }^{3} \sigma^{\text {.. are }}$

Uslar Pietri's view is supported by David E. Blank, who argues that Venezuelan politics have revolved around oil since this was discovered at the turn of the twentieth century. ${ }^{37}$ Accordingly, oil has not only changed the country inside, but its traditional posture of submissiveness toward external actors, has also changed. Oil has indeed provided support for Venezuela's newly aggressive regional politics.

Franklin Tugwell also stresses the importance of oil in Venezuela. He argues that Venezuela's government and the economy have become so dependent on oil earnings, that oil politics have come to operate as an independent variable in regard to most other policy-making areas. ${ }^{38}$ It is clear that Tugwell feels that all other areas of policy-making in Venezuela depend on the politics of oil. Perhaps one of the most accurate descriptions of the Venezuelan situation is that made by Sheldon B. Liss. Regarding the idea that oil determines Venezuela's foreign and domestic policies Liss states that: "Venezuela realizes that its domestic future 
depends heavily upon its international economic relationships, and its foreign policies are, more than ever, determined by the oil industry ..."39 Accordingly, if Venezuela is to have a chance to develop it must successfully manage its oil policies; and its oil policies and foreign policy, must be in complete harmony.

Another factor that has significantly conditioned Venezuela's foreign policy is that of perceived external political and economic threats, and how these external threats relate to domestic concerns. As we shall see in our analysis, there seems to be evidence supporting the view that there is a relationship between democratic institutionalization in Venezuela and the conduct of foreign policy. As stated by Charles D. Ameringer: "The conduct of foreign policy provided yet another means for measuring the institutionalization of Venezuelan democracy ... the president's style in foreign affairs reflected his perceptions of internal conditions." 40 some scholars would disagree with Ameringer's view, however, we must remember that after 1958 the survival of democracy was paramount because presidents were aware that social and economic reforms could have lasting impact only if put into effect by solid and durable institutions. 41 This so called Venezuelan democratic institutionalization was obviously inextricably linked to oil revenues, for the nation's dependence on oil 
had become so profound that the post-1958 reformist programs would have been impossible to carry out without oil revenues. A final factor, one that has significantly conditioned Venezuela's foreign policy, is that of U.S. hemispheric domination.

\section{Approach and Methodology}

We will begin with the proposition that: foreign policy is not determined by ideas but by other more tangible factors. Obviously, this is an abstract proposition and the study will need to move to a more concrete level. Tentatively then we believe that: Venezuela's foreign policy during the era of the Betancourt Doctrine and Caldera's Ideological Pluralism was determined by the political and economic interests pursued and not by ideology. The main task will be to demonstrate the relationship between political economy and ideology, and how, and to what extent, ideology can be used to justify and/or hide the pursuit of political and economic interests in making foreign policy.

We will need to establish indicators that will determine the relationship between variables. Some of these indicators are: the number of countries of ideologically different regimes with which Venezuela suspended relations during the era of Betancourt Doctrine; the number of countries with which Venezuela sustained "aggressive" relations during 
the same period, (the Dominican Republic and Cuba); Venezuela's political, economic and military support for democracy in the hemisphere during the period of Betancourt; policies that ideologically supported the United states position during Betancourt's period, (support for the Alliance for Progress). Operationalization will also occur thorough the number of countries of ideologically different regimes with which Venezuela renewed relations during the period of Caldera's Ideological Pluralism; the number of statement that support Venezuela's commitment to ideological pluralism and why the Betancourt Doctrine was abandoned; Venezuela's advocacy of an oil price increase and how this was related to international social justice.

Analysis will also include a study in terms of Venezuela's reasons for joining the Andean Common Market in February, 1973; Venezuela's attempts to control the oil industry, including Venezuela's initiative to form OPEC; attempts to diversify the economy; attempts to diversify Venezuela's business partners; attempts to dominate the region through oil wealth.

The issue of dependency will be treated in terms of Venezuela's dealings with a dominant power, the United States. These dealings with the United States will consist of the following: dealings with the U.S. government, and, dealings with North American oil corporations. The objec- 
tive then will be to determine whether, and to what extent, these dealings with a dominant power (United States), influenced or determined the foreign policy of a dependent state, (Venezuela).

We assert tentatively then that: 1) Betancourt's foreign policy was not determined by ideology but by the domination of the United States in the Western hemisphere, and by Betancourt's commitment to improve Venezuela's economic condition as a means for him to remain in power. Also, Betancourt sought to take the best possible advantage of the dependent situation he was in under U.S. capitalist expansionism. 2) Caldera's commitment to expand Venezuela's regional influence and economic power through wealth, determined Venezuela's foreign policy during the period of Caldera's Ideological Pluralism. Also, Caldera's foreign policy was to a considerable extent determined by the hemispheric economic and political influence of the United States. Ideology was for Caldera, as well as for Betancourt, only the means to rationalize their foreign policy decisions.

It becomes important to note that such concepts as ideology and politics are difficult to measure. For this reason, we use indicators that only relate indirectly to the concepts they intend to measure. Therefore, the possibility for error and the limitations of the present study are obvi- 
ous. In other words, it is quite clear that it is difficult to apply "measurements" to the variables utilized in the present study, the problem therefore to assess validity and reliability in this particular study becomes obvious. The objective of this exercise, then, is to prove or disprove the tentative assertions mentioned above, and to see to what extent the findings support or refute some of the assumptions of some foreign policy theorists.

Finally, data utilized for this study has been selected from primary sources, that is, newspapers, interviews, addresses to the nation, addresses to international conferences and organizations. This technique obviously assumes that the articulations of individuals are reliable indices of their actual actions in formulating and carrying out foreign policy. The present study also relies on secondary sources, that is, articles and books relevant for the purpose of this thesis. 


\section{CHAPTER II}

\section{VENEZUELA'S FOREIGN POLICY DURING THE PERIOD OF THE BETANCOURT DOCTRINE}

This chapter will attempt to answer the following questions: Was the Betancourt Doctrine purely ideological (Betancourt's commitment to democracy in Venezuela and in the hemisphere)? Was the Betancourt Doctrine just a facade to justify the pursuit of political and economic interests or, was it a combination of both, commitment to democracy and the pursuit of political and economic interests?

The main theme to be developed is that Betancourt's foreign policy was mainly determined by U.S. hemispheric domination. Venezuela's foreign policy was determined also by Betancourt's commitment to improve Venezuela's economic conditions as a means for him to remain in power. In order to improve Venezuela's economy and remain in power, Betancourt sought to enlarge Venezuela's dominance over oil resources and the oil industry while at the same time he sought to take the best possible advantage of the dependent situation he was in under the capitalist expansionism of the United States. Good economic performance would in turn ensure the survival of Betancourt's government. 
In an analysis of Venezuela's foreign policy during the period of the Betancourt Doctrine, the following topics will be discussed in order to illustrate that policy:

1. Venezuela's foreign policy toward Trujillo's Dominican Republic.

2. Venezuela's foreign policy toward Castro's Cuba.

3. Venezuela's foreign policy toward the United States.

4. Venezuela's foreign policy and the economics and politics of oil: The Case of OPEC.

Venezuela's foreign policy during the period of the Betancourt Doctrine (1945-1948 and 1959-1963) cannot be discussed adequately without briefly exploring the pattern of that policy prior to 1945. This exercise is important because it shows that there were significant changes brought about in the economic and political structures of Venezuela that had a direct impact on foreign policy.

The most significant change in the economic structure of Venezuela, was that it changed from a mono-product economy based on agriculture, to a mono-product economy based on petroleum. Prior to 1917 Venezuela's economic welfare depended on coffee and cacao exports. This economic pattern resulted in delayed and dependent development. In 1917, however, petroleum began to be exploited for commercial purposes and slowly began to replace agricultural 
products as the main source of revenues. By 1945, the year Betancourt first came to power, petroleum exports accounted for 93.4 per cent of Venezuela's exports. ${ }^{1}$ Because the United States was the major buyer of Venezuela's petroleum, and because the oil industry was dominated by U.S. oil corporations, the economy became for the most part dependent on foreign firms. This economic pattern resulted in outward oriented development that limited the effectiveness of Venezuela's political sovereignty.

Venezuela's political structure, on the other hand, changed from one almost totally dominated by dictatorial military regimes, to one almost exclusively controlled by civilian governments after 1945. Between 1908 and 1935 the dictator Juan V. Gomez had ruled Venezuela as his personal farm. Gomez personally made large profits from the oil industry and ruled Venezuela in an uncontested fashion. He simply exiled or murdered all his political opponents. The oil industry and the exiling of political enemies, though initially beneficial to Gomez's dictatorship, in the long run proved fatal to that type of government. The scientific, technological and economic benefits brought by the oil industry, coupled with the generation of exiles who lived and studied in the United States and Europe, where they had been exposed to democratic, development-oriented 
government, demanded a new type of government orientation for Venezuela after 1945, John V. Lombardi states:

"These new people did not subscribe to
the old-fashioned notions of Venezuela
as rural hacienda ... They returned to
help re-create Venezuela's future, they
brought with them sophisticated notions
about investment,
industrialization, "social welfare and
individual rights."

In addition, petroleum revenue greatly enhanced the possibilities of the new leaders for political changes and populist reforms.

In summary then changes effected in the economic and political structure after 1945 showed how the country moved from delayed and dependent development (1825-1935) to outward oriented development (1880-1935) and unto state-led capitalism or the populist era (1945-1948 and 1959-1963).

1. Venezuela's Foreign Policy Toward Trujillo's Dominican Republic.

The consideration of Trujillo's Dominican Republic is important because it shows that the Betancourt Doctrine was applied to dictatorships of the right as well as those of the left. The main idea here is that Betancourt applied to Trujillo the Betancourt Doctrine because Betancourt was committed to remain in power, and he feared to be overthrown 
by Trujillo - like opposition, namely, military men. Economic problems and the cold war also contributed to Betancourt's application of his doctrine to Trujillo. Finally, the protection and promotion of Venezuela's oil interests led Betancourt to play the anti-dictatorship game through the Betancourt Doctrine.

The Betancourt Doctrine simply stated is: that no government that was not democratically elected, that achieved power by forceful means and furthermore, that was not representative of the will of the people, deserved recognition of the American states. Accordingly, Venezuela abstained from relations with any such dictatorial governments and sought their expulsion from the Organization of American States. The Betancourt Doctrine sought to discourage coups against democratically established governments, meaning that it tried to function as a deterrent to the rise of dictatorships.

Through the Betancourt Doctrine, Betancourt sought to convince the American republics, especially the United States to abstain from recognizing dictatorial governments. Betancourt feared that, if this were not the case, his government could be toppled by the military at any time. The issue of the United States recognition became crucial to Betancourt if dictatorships were going to be discouraged and isolated. This reflects the influence of the United States 
on Betancourt's foreign policy. From Washington's point of view there were, however, some factors that did not at all coincide with Betancourt's goal.

First of all, it must be remembered that during the 1940's Trujillo and the United States had good relations. During that period Trujillo was strongly criticized by the Latin American left. Obviously, this was a favorable point for Trujillo in the context of his relations with the United States. In addition, it was during this period that the Superpowers began to fight the Cold War and Latin America was not exempt. The United States feared the spread of communism in Latin America and considered that dictators of the right were the best way to combat that ideology. Paul S. Holbo argues that after the end of World War II, when most Latin American countries were ruled by authoritarian governments, the Latin American democrats, whose power had been usurped or denied, hoped in vain that the United States would help to depose the despotic regimes because "the Cold War underlayed dealings with dictators."3 In addition, Larman C. Wilson states that in order to maintain good relations with the United States, all that Trujillo, Duvalier and other dictators of America needed to do was to play the "anti-communist game." 4

Secondly, Betancourt himself may have complicated his problems, and he lacked U.S. support when he most needed it. 
Betancourt's 1945-1948 populist reforms may have been perceived as too radical in the United States, and as a result, this U.S. perception, or misperception, may have indirectly contributed to the overthrow of A.D. (Acción Democratica) in 1948. In Venezuela: Oil and Politics, Betancourt argues that while Perez Jimenez and other major military leaders were planning to topple $A D^{\prime} s$ government, the United States proceeded to recognize the de facto government of General Manuel Odría in Peru. This action by the U.S., Betancourt argues, stimulated the Venezuelan plotters to carry out their illegal usurpation of power. As Betancourt himself puts it:

"The victorious insubordination of Odria
in Lima accelerated the plans of those
disturbers of order... the washington
government recognized the de facto
regime of odria ... the result of a
military coup $\ldots$ the Caracas
conspirators took this attitude of the
United states as a 'green light for an
uprising'."5

Again, Betancourt sought to protect his government by applying the Betancourt Doctrine to Trujillo and all dictators in the hemisphere. Failure to get the United States to withhold recognition from such regimes contributed to the deposition of the $A D$ of Betancourt in 1948. The United States was obviously more concerned with the advance 
of Communism than with protecting Betancourt's interests in Venezuela. Betancourt's relationship with Trujillo in 19451948 was indeed conditioned by a major pragmatic political factor, namely that Betancourt saw his preservation of power threatened by Trujillo and Trujillo - like governments.

In 1959, after ten years of the Perez Jimenez military dictatorship, Betancourt regained power in Venezuela, and he immediately recalled the Betancourt Doctrine as a hallmark of Venezuelan foreign policy. Some extremely important events took place that led to his election and these should be mentioned. The most important one is that Betancourt himself took part in a coalition movement that overthrew Perez Jimenez and governed the country for the next five years. The formation of the Punto Fijo Pact, the political coalition between $A D$, COPEI (Comité de Organización Política Electoral Independiente) and URD (Unión Republicana Democratica) was one of the most important events that led to Betancourt's election. Without this coalition, Betancourt would not have been reelected Venezuela's president. It is important also to note that economic and political forces returned to power the same populist party that had been overthrown in 1948, namely, Betancourt's Acción Democrática.

In order to explain how the aforementioned factors contributed to Betancourt's return to power, it is necessary 
to understand the repercussive effect of certain events in the Latin American republics. As stated by Harry Kantor: "Although ... independent of one another what happens in any one [Latin American republic] influences what happens in the other."6 Betancourt's own previous experience ten years earlier (1945-1948) proved Kantor's argument correct. The overthrow of $A D$ in 1948 was, to a considerable extent, motivated by the wave of coups that was sweeping the region. By 1959, events in other Latin American countries again influenced Venezuela, but this time to Betancourt's benefit. In order to depose dictatorial governments, political coalitions were formed in several Latin American countries besides Venezuela, as for example the coalition between liberals and conservatives in Colombia.

Venezuela was then impacted by such events going on in other Latin American countries, and in 1958 a coalition was formed in Venezuela, the Punto Fijo Pact. According to the Pact of Punto Fijo AD, COPEI and URD agreed to: "abide by election results, uphold the constitution and to share cabinet positions."7 This coalition proved to be a crucial step to ensure the continuation of the politics of democratic government in Venezuela.

Another important factor that led to the election of Betancourt was the influence of $A D^{\prime} s$ populism. The people, dissatisfied with the politics of Perez Jimenez's 
dictatorship, sent to the presidency the same populist reformist party that had been overthrown ten years earlier. In this, as Judith Ewell writes, $A D$ had a second chance at implementing its populist programs:

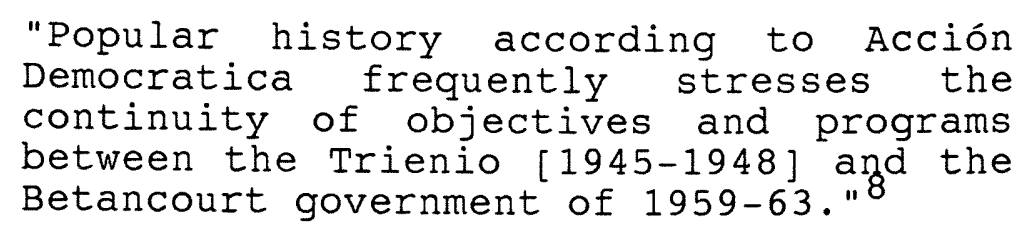

With Betancourt's and $A D^{\prime}$ s populist reforms, there was a turn from Perez Jimenez's "laissez faire," outward oriented development, to Betancourt's state-led capitalism and social justice.

Betancourt hoped populism would this time prevail in Venezuela. He also hoped that by bringing out the Betancourt Doctrine against Trujillo and the remaining dictatorships, he would isolate them and eventually encourage the rise of populist governments similar to his own in the hemisphere. He seemed to acknowledge that his government's survival depended on the emergence of kindred systems in the region. As noted by Robert J. Alexander: "A steady drift towards military dictatorship elsewhere in Latin America ... might seriously impair the venezuelan regime." 9

Another important factor that determined Venezuela's foreign policy toward Trujillo's Dominican Republic was that 
Betancourt faced serious economic problems and he was desirous to show the United States that he was not a communist, as some in the United States had perceived him in his previous 1945-1948 populist reforms. Betancourt also needed to show the United States that he was a better alternative to oppose communism than dictators of the right. That is why in 1959, in the midst of the cold War, Betancourt did not only recall and apply the Betancourt Doctrine, but added a new element to it, namely, that right wing dictators had to be isolated because they engendered communism. Betancourt himself said that "the challenge before us is ... to thwart the prosperity of governments not elected by the people, because they engender communism."10 This simply underlines how Betancourt was trying to turn against Latin American dictatorships and play the anticommunist game that brought so many benefits from the United States. In order to support his claims against dictatorships, Betancourt argued that the communists in Venezuela dominated labor unions and held government positions during the period of Perez Jimenez dictatorship, something, according to Betancourt, that never took place during his previous 1945-1948 government. 11

Betancourt was fortunate that by the beginning of the 1960 's the United States was not giving all-out support to the Dominican dictator. Trujillo had refused to collaborate 
with the U.S. government against Castro's Cuba, and this refusal brought about a deterioration in U.S.-Trujillo relations. Betancourt, quite to the contrary, sought the economic and political benefits of cooperating with the United States against Castro.12 United States' political and economic support was vital for Betancourt to remain in power and for $A D^{\prime} s$ government to survive. Government survival indeed depended in large measure on the success of Betancourt's economic reforms, and successful economic reforms needed large sums of money, and the U.S. was the most accessible source for that money.

In this context of Betancourt's need for good relations with the United States, it is necessary to understand that Venezuela's economic welfare depended upon oil and upon a mostly American controlled oil industry. Venezuela's oil. revenues were indeed heavily conditioned by American oil companies operating in Venezuela, and by the fact that the United States was the number one customer for Venezuela's crude. Thus, through the Betancourt Doctrine, Venezuela began to play the anti-communist game in order that it might not lose its most favorable position in the U.S. market. This was not unfounded because, as Enrique Baloyra notes, upon Betancourt's return to power his regime was pressured by a series of "momentous events" that prompted fear and a response by the Venezuelan government. Among the events, 
Baloyra writes, was that on March 10, 1959, when "President Eisenhower issued a proclamation establishing mandatory control of oil imports to the U.S."13 This further complicated Betancourt's economic problems and reflects the failure of the Betancourt Doctrine in getting the most favorable conditions for Venezuela's oil in the U.S.' market.

In the end, Venezuela's foreign policy toward Trujillo's Dominican Republic was one marked by animosity between Betancourt and Trujillo. It was not, however, this animosity that led Betancourt to apply the Betancourt Doctrine to Trujillo, but it was rather Betancourt's fear that a Trujillo-like military man might topple the AD government. In addition to the problem of fear of being overthrown, there were also economic problems urging Betancourt to apply his doctrine to right as well as left wing dictatorships in order to procure United States economic favors. Finally, seeking to flatter the U.S. government, Betancourt stressed his doctrine against Trujillo, especially after Trujillo's impasse with the United States when he refused to cooperate with Washington against Castro's Cuba. 
2. Venezuela Foreign Policy Toward Castro's Cuba

Castro's Cuba is an important topic in terms of the present study because it shows how the protection of the United States' security interests in the hemisphere conditioned the foreign policy of Betancourt. It will be argued that while Betancourt may have played his cards right, meaning that for whatever interests he was committed to remain on the side of the U.S. rather than on Castro's, the main factor determining his foreign policy toward Castro's Cuba, had to do with U.S. pressure. It will also be argued that Betancourt's and Castro's divergent views regarding the U.S. came as a consequence of Betancourt's political pragmatism more than adherence to any ideological position or any anti-dictatorial doctrine.

In order to understand how responsible the United States was for Betancourt's foreign policy toward Castro, it must be pointed out that the United States was the major single purchaser of Venezuela's oil, and Venezuela was one of the largest recipients of U.S. foreign investments. Also, Venezuela's economic recovery and Betancourt's political survival depended on U.S. economic aid and U.S. capitalist expansion.

The first part of the argument has to do with U.S. pressure on Betancourt. U.S. pressure showed in economic and political ways. The United States was well aware that 
for Betancourt to remain in power, the inflow of U.S. capital was vital. That is why it is not difficult to explain why Betancourt's AD, a populist oriented party, opened up the doors to U.S. capitalist expansion. Betancourt knew that the survival of his government depended on the protection and promotion of U.S. economic interests in Venezuela, and that U.S. capitalist expansion was crucial for his political survival. Carlos Capriles Ayala, argues that after Betancourt took power, Venezuela's front gate became wide-open to foreign capitalism which penetrated the country and expanded spectacularly.14 Daniel Hellinger states that "AD policies were ... consistent with the interests of expanding transnational capital."15 Some apologists argue that opening up the doors to foreign capital was a necessary measure since Venezuela was so dependent on oil, and the economy had to be diversified. 16 The true reason for $A D^{\prime} s$ attitude toward U.S. capitalist expansion, however, was that Betancourt saw that the survival of $\mathrm{AD}^{\prime}$ s government depended, in large measure, on U.S. capital inflow. It is no wonder that, as steven Ellner says, "Betancourt attempted to make a showcase of his ... enterprises in order to reduce prejudice against foreign investment."17 (Table 1 shows the level of U.S. investment in Venezuela during the Betancourt period.) 
$\underline{T a b l e ~} 1$

U.S. DIRECT INVESTMENT IN VENEZUELA

1959 TO 1963

[Millions of U.S. Dollars]

\begin{tabular}{|c|c|c|c|c|c|}
\hline Year & Total & Petroleum & Manufacturing & $\begin{array}{c}\text { Transport } \\
\text { Communicati } \\
\text { and } \\
\text { Utilities }\end{array}$ & Trade \\
\hline $\begin{array}{l}1959 \\
1960 \\
1961 \\
1962 \\
1963\end{array}$ & $\begin{array}{l}2,690 \\
2,569 \\
3,007 \\
2,816 \\
2,808\end{array}$ & $\begin{array}{l}2,046 \\
1,995 \\
2,368 \\
2,197 \\
2,166\end{array}$ & $\begin{array}{l}161 \\
180 \\
195 \\
193 \\
202\end{array}$ & $\begin{array}{l}29 \\
32 \\
34 \\
35 \\
36\end{array}$ & $\begin{array}{l}166 \\
165 \\
185 \\
175 \\
185\end{array}$ \\
\hline
\end{tabular}

Source: James W. Wilkie and Adam Perkal, Eds., Statistical Abstract of Latin America, Volume 24 (Los Angeles: UCLA Latin American Center Publications, University of California, $1985)$, p. 669 .

The dependency of Betancourt on U.S. capital expansion can be better stated in terms of Cardoso and Faletto's framework. Accordingly, U.S. capital kept the Betancourt government alive through the inflow of money destined to reach the dominant classes in Venezuela. In this process of capital transfer, the Venezuelan state, headed by Betancourt, served as a mediator between U.S. capital and the Venezuelan dominant classes. As stated by Cardoso and Faletto: 


"During this process the role of the
state augments ... in effect ... the
state ... acts as mediator for the
politics of of financing foreign
investments."18

This situation, then, created a condition of dependency from which Betancourt could not escape. Again, Cardoso and Faletto state:

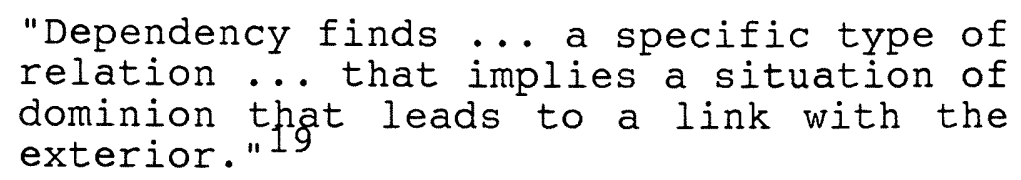

Cardoso and Faletto furthermore mention that with the injection of foreign capital into the dependent country's economy, there develop "consequences evidently restrictive as to the autonomy of the national economic system and political decisions." 20

Also, it is important to note that U.S. pressure on Betancourt which influenced his foreign policy toward Castro had much to do with the fact that Venezuela's oil was strategically important to the United States (Venezuela provided most of the oil coming into the United states). The United States could not afford to lose oil-rich Venezuela to Communism. Therefore, in order to protect economic and security interests, the United States was urged to pressure Betancourt, so that Betancourt would maintain a 
strong stand against Castro. Commonweal's March 8, 1963 issue voiced the importance of Venezuela's mineral riches to the United States, "[Venezuela's] vast oil and iron resources are of key importance to the West."21 Samuel Shapiro expresses also this U.S. concern over Venezuela, "a crucial test of our policies will come in Venezuela, Cuba's Caribbean neighbor ..."22

From the foregoing it can be seen that the United States was pursuing its interests in Venezuela because oil was a vital element for American industrialized society and because the American oil industry had much at stake in Venezuela. It is no wonder then that the oil industry worked in partnership with the $A D$ government. Cooperation was in the industry's own economic interests, and in those of the United States.

The second aspect of the discussion has to do with Betancourt's political pragmatism. It can be argued that while subject to U.S. pressure and dependence on the U.S., Betancourt played his cards right, meaning that by remaining on the side of the U.S., rather than on Castro's, Betancourt derived the most political and economic benefits. Betancourt's and Castro's divergent views regarding the U.S. will illustrate the aforementioned assertion.

Fidel Castro visited Venezuela immediately after taking over the government in Cuba, January 23, 1959. The primary. 
objective for his visit was to thank the Venezuelan people for the support given to the cuban revolutionaries of the Sierra Maestra during their fight against Batista. However, as Castro's speeches in Venezuela reflect, rather than thanking the Venezuelan people, Castro launched an unrelenting attack against the United States. He spoke with frenzy, and accused the U.S. of being imperialist. In his two days' visit to Venezuela, Castro stirred the masses, especially those belonging to the Venezuelan Communist party, and before his departure for Cuba, he had an interview with Betancourt.

In that interview, according to Betancourt, Castro asked him a $\$ 300$ million loan to free Cuba from dependence on the United States, and to stir up trouble for the American government. Betancourt replied that Venezuela was not in a position to make such a loan. That apparently disgusted Castro and he left Venezuela in anger. 23

That interview was the beginning of the animosity between Castro and Betancourt. It shows, however, the pragmatism of Betancourt because, if Betancourt had played Castro's trick on the United States, the U.S. economic and political reprisal against Betancourt could have been devastating to his government.

The potential existed, then, for inflicting damage on Venezuela. The United States had already imposed mandatory 
control of oil imports to the U.S. As a result of the U.S. government proclamation on imported oil, Venezuela suffered considerably. It was indeed a difficult time for the Venezuelan government because import quotas limited large increases in production and consequently, oil revenues declined.24 Oil, as C.A. Hauberg puts it, "was the mainstay for the [Venezuelan] economy and consequently the budget was in bad shape."25 A further cut imposed on Venezuela's oil quota to the U.S., in reprisal for having followed Castro's request in regard to the U.S., could have been disastrous to Betancourt's government. Thus, Betancourt chose to gain Castro's enmity, rather than to bring upon his government and upon him personally any reprisal by the United States.

The Alliance for Progress is another factor that influenced the pragmatist, Betancourt, and his foreign policy as he tried to make the best of the situation while under pressure from the United States. According to Robert F. Aide, the rationale behind the Alliance for Progress was to prevent communist intrusion in the Western Hemisphere. Due to precarious economic and social conditions in Latin America, the people could be extremely susceptible to communist-inspired revolutions of the Cuban type. 26 Through the Alliance for Progress, the economic and social conditions of the Latin Americans could be improved, thus diminishing the risk for Communist intrusion. 
In Venezuela, too, the stated goal was to make the Alliance successful in order to diminish the appeal of Castro's radical revolutionary model. Betancourt became resolutely committed to extract maximum economic and political benefits from the U.S. because he knew that the U.S. was particularly interested in Venezuela. Venezuela supplied a considerable part of the Western hemisphere's oil including a vital part of the U.S. supply. As can be seen in Table 2, the level of U.S. government foreign aid to Venezuela tends to increase with each year that Betancourt was in power.

\begin{tabular}{|c|c|c|c|c|}
\hline \multirow[b]{2}{*}{1959} & $\frac{\text { U.S. }}{\underline{A I}}$ & $\frac{\text { RNMEN }}{\frac{\text { EDITS }}{1959}}$ & $\frac{\text { EIGN }}{\text { ENEZUH }}$ & \\
\hline & 1960 & 1961 & 1962 & 1963 \\
\hline 3 & 6 & 32 & 64 & 43 \\
\hline
\end{tabular}

Source: U.S. Department of Commerce, Historical Statistics of the United States, Colonial Times to 1970, september 1975, pp. 873-875.

In conclusion foreign policy toward Castro's Cuba was primarily conditioned by the U.S. display of economic and political power in protecting its security interests in the 
hemisphere. U.S. pressure upon Betancourt urged him to remain an all-out supporter of United States anti-Castro policies. That is why Betancourt unrelentingly applied the Betancourt Doctrine to Castro's Cuba. It is important to note again that while he was no doubt pressured by the U.S., Betancourt's political pragmatism allowed him to take advantage of a difficult situation. That is why his commitment to apply the Betancourt Doctrine to Castro can also be explained in terms of the U.S.'s urgency in protecting economic and security interests in Venezuela. Betancourt elicited substantial amounts of Alliance for Progress funds in order to carry out successful economic and social reforms that would maintain the $A D$ party and himself in power.

3. Venezuela's Foreign Policy Toward the United States Betancourt's foreign policy toward the United States was primarily conditioned by the globalization of U.S. capital expansion and by Betancourt's economic problems. With the approval of the U.S. government, Betancourt imposed higher taxes on American oil companies operating in Venezuela in order to consolidate his power. Moreover, as already suggested, the United States used the Alliance for Progress to protect and promote security interests in the hemisphere, particularly in Venezuela, and took political 
advantage of Betancourt by letting him use substantial amounts of Alliance for Progress funds.

The beginning of the 1960's were difficult years for the world economy. A world-wide economic recession affected all, and Venezuela's economy, completely dependent on oil, was particularly impacted because of the drop in the price of oil. This complication of the economic situation, in turn, seriously threatened the *political survival of Betancourt's government. The United States, on the other hand, took advantage of Betancourt's economic and political problems to further expansion in Venezuela by increasing U.S. investments and foreign grants and credits to that country. Samuel Shapiro notes that during this time, 19611962, the Venezuelan budget had a $\$ 250$ million deficit despite Betancourt's previous $\$ 200$ million loan from fifteen U.S. banks just one year before. 27 This difficult economic situation led Betancourt to look again for U.S. foreign assistance. Table 3 shows the increase in U.S. total investments in Venezuela during the period of Betancourt (1959-1963), in relation to the 1950-1956 period. In addition, Table 4 reflects the increase in U.S. foreign grants and credits to Venezuela during the Betancourt period, in relation to the previous nine years. 


$$
\frac{\frac{\text { Table } 3}{\text { U.S. DIRECT TOTAL INVESTMENT IN }}}{\left[\frac{\text { VENEZUELA }}{1950-1956 \text { AND 1959-1963 }}\right.}
$$

$\begin{array}{rrrrrrr}1950 & \underline{1951} & \underline{1952} & \underline{1953} & \underline{1954} & \underline{1955} & \underline{1956} \\ (993) & (968) & (1,134) & (1,237) & (1,275) & (1,311) & (1,676) \\ & \underline{1959} & \underline{1960} & \underline{1961} & \underline{1962} & \underline{1963} & \\ (2,690) & (2,569) & (3,007) & (2,816) & (2,808) & \end{array}$

Source: James W. Wilkie and Adam Perkal, Eds. Statistical Abstract of Latin America, Volume 24 (Los Angeles: UCLA Latin American Center Publications, University of California, 1985), pp. 668-669.

\section{$\underline{\text { Table } 4}$ \\ U.S. FOREIGN AID TO VENEZUELA IN GRANTS AND CREDITS \\ $1950-1956$ AND 1959-1963 \\ [ In millions of U.S. Dollars]}

$\begin{array}{rrrrrrr}\underline{1950} & \underline{1951} & \underline{1952} & \underline{1953} & \underline{1954} & \underline{1955} & \underline{1956} \\ (Z) & (1) & (4) & (Z) & (-3) & (Z) & (-3) \\ \underline{1957} & \underline{1958} & \underline{1959} & \underline{1960} & \underline{1961} & \underline{1962} & \underline{1963} \\ (-1) & (-1) & (3) & (6) & (32) & (64) & (43)\end{array}$

- Represents zero

$z$ less than $\$ 500,000$.

Source: U.S. Department of Commerce, Historical Statistics of the United States. Colonial Times to 1970, September 1975, pp. 873-875. 
Indeed, there seems to be a direct correlation between Betancourt's economic problems, his need to overcome the economic crisis as a means to maintain the $A D$ party and himself in power, and U.S. capital expansion in the form of foreign investments and foreign grants and credits. Tables 3 and 4 portray the rise of U.S. foreign investment and foreign aid to Venezuela and may be interpreted as a measure of the relative importance of U.S. capitalist expansion in conditioning Betancourt's foreign and domestic policies.

The second print of the argument is that Betancourt used Venezuela's oil to consolidate his position in power. Betancourt did not do this autonomously, however, because he had to have the approval of Washington in order to impose higher taxes on American oil companies in Venezuela. For AD to remain in power, it had to carry out successfully agrarian, economic and social reforms, and consequently, a new source of revenues had to be created. As oil was the Venezuelan economy's mainstay, $A D$ thought it convenient to impose higher taxes on American oil corporations in order to acquire the necessary extra revenue that the government needed. As stated by Loring Allen, "the [AD] government needed revenues desperately to support its reforms ... The petroleum industry was the only source." 28

In support of the foregoing argument, Hellinger asserts that $A D^{\prime} s$ leaders decided to speed up the land reform 
program in order to prevent a suspected military coup. 29 Land reform programs, however, had to proceed on the basis of compensated expropriations if the government was to avoid the worst consequences of an outraged landowning class. The government, then, was so preoccupied with keeping power that it rushed to carry out reforms at the expense of imposing higher taxes on American oil companies. Alexander states that the $A D$ government,

"sought to establish firm control over the country's principal source of income ... [and] it sought to use this increased income ... to establish the basis for ... government." 30

It is worth emphasizing that the Betancourt government's initiative to increase taxes on American oil companies was an agreement that had to be approved by the U.S. government. Accordingly, the oil companies were then permitted to charge this tax against their profits at home, which explains why the U.S. companies did not lose. This clearly reflects the extent to which U.S. capital expansion and U.S. pressure, conditioned the foreign and domestic policies of Betancourt's government.

The final point of the foregoing discussion is that the United States, in order to pursue security interests in the hemisphere, took political advantage of Betancourt by 
letting him use substantial amounts of Alliance for Progress funds. Even though other nations, Bolivia, the Dominican Republic, Chile, etc., received more Alliance aid per capita than Venezuela, because of its civilian form of government and its oil wealth, Venezuela came to be one of the main showcases for the Alliance.

William C. Olson argues that one of the most striking examples of the role political and economic interests can play in determining foreign policy, is that developed by the United States during the Cold war:

"As the Cold War developed and the United States found itself engaged in a struggle with the Soviet Union for influence in the Third World, a far more elaborate use of economic assistance as a weapon of foreign policy began to be
deployed." 31

Castro's turn to the Soviet Union was the major factor that awakened U.S. interest in the region. This point was implicitly conveyed in President Kennedy's speech when he visited Venezuela in December 16, 1961:

\footnotetext{
"[This is] an Alliance for the protection of our countries ... one of the main objectives ought to be ... the elimination of tyranny." 32
} 
Kalman H. Silvert states that "the United States interpreted a communized Cuba as a threat above all else to national security ..."33 silvert's argument coincides with Venezuelan Jose A. Silva Michelena:

"It had become clear to the United States that economic development ... of Latin America was a vital need for its own internal security."

This United States' attitude toward Latin America, then, proves correct Robert F. Aide's argument that the United States takes an active interest in Latin America only when it perceives a direct threat to its own security or economic interests. 35

From the above, it could be therefore argued that Venezuela was one of the countries where the United States took most active interest in preserving its own security. It appears, then, that Venezuela, for its oil wealth, and its civilian government, was one of the most appropriate places to make the Alliance work. Referring to Venezuela, Shapiro argues that, "if... reforms do not work here, they are not likely to be successful in less richly endowed Latin American states."36 Also, Kennedy himself declared in his speech on the occasion of his visit to Venezuela, "here in Venezuela the true meaning of the new Alliance for Progress is manifested." 37 Kennedy hoped that if the Alliance could 
work in Venezuela, it would inspire faith in other countries that the same miracle could work for them, thus diminishing their desire to experiment with Castro's model. Table 5 shows that Venezuela had the highest rate of growth of per capita income in Latin America for the period of the Alliance, 1961-1965. There can be then some correlation between Venezuela's appropriateness for the Alliance, foreign aid received and improvements in the rate of growth. This is not to deny that there were five other countries that ranked higher than Venezuela in the amount of Alliance for Progress funds received.

\section{Table 5}

THE AVERAGE RATE OF GROWTH OF PER CAPITA INCOME

IN LATIN AMERICA, 1961-1965

$\begin{array}{lr}\text { Argentina } & -0.1 \\ \text { Bolivia } & 2.0 \\ \text { Brazil } & 0.2 \\ \text { Chile } & 1.7 \\ \text { Colombia } & 1.6 \\ \text { Ecuador } & 1.4 \\ \text { Mexico } & 3.4 \\ \text { Panama } & 3.9 \\ \text { Uruguay } & -1.4 \\ \text { Venezuela } & 4.2\end{array}$

Source: Cole Blasier ed., Contemporary Change in Latin America, (Pittsburgh: University of Pittsburgh Press, 1968 ) pp. 134.

In conclusion, it appears clear that Venezuela's foreign policy toward the United States during the period of the Betancourt Doctrine was indeed primarily conditioned by 
U.S. capitalist expansion and Betancourt's economic problems. Accordingly, the United States took advantage of Betancourt's economic problems to promote U.S. capital penetration in Venezuela. Betancourt needed desperately to overcome an economic crisis in order to maintain his hold on the government. The United States, then, provided him with the means to stay in power, by increasing foreign investments and foreign grants and credits to Venezuela.

Also, Betancourt's oil policies were geared toward maintaining a balance between economic prosperity and political survival. In order to keep power, Betancourt had to carry out successful economic reforms; to do that, a new source of revenue was needed, and American oil companies became the source. Regrettably, Betancourt had to first have U.S. government approval in order to impose a new tax on American oil companies operating in Venezuela. Finally, Betancourt believed he was gaining substantial economic benefits from the United States' Alliance for Progress, but in fact, as Venezuela's social scientist Silva Michelena argues, "they were... helping to reaffirm dependency and defend U.S. internal security and other interests." 38 
4. Venezuela's Foreign Policy and the Economics and Politics of Oil: The Case of OPEC

A complete analysis of the politics and economics of Venezuelan oil is clearly beyond the scope of this study. I can, however, attempt to demonstrate the intertwining of the economics of oil and politics. The main argument is that United States capitalist expansion, coupled with a drop in the price of oil, pushed Betancourt to seek alliance with other oil producing countries in the Middle East, in order to get a fairer return for Venezuela's oil resources. It can also be said that in seeking to participate in OPEC (Organization of Petroleum Exporting Countries), Betancourt may have overlooked the Betancourt Doctrine, meaning that he collaborated with non-democratic governments, but in fact Betancourt was adhering to, and going along with populist $\operatorname{logic}$.

Central to the understanding of Venezuela is the close link between politics and oil. Oil wealth, political stability, and progress are inextricably related. Martz and Myers tend to agree:

\footnotetext{
"Venezuelan political elites [have] the ... conviction that properly used petroleum wealth holds the key to national control over the economy, "350
progress... to economic development."
} 
In his 1959-1963 period, Betancourt, too, acknowledged that oil, economic development and political stability, were inseparably related. He saw very clearly that the survival of his government, and the political survival of A.D. and himself, were heavily dependent on oil revenues. However, to Betancourt's disadvantage, United States pressure and other economic problems seriously impaired Venezuela's economy. Romero argues that Betancourt's government had serious economic problems and "found itself between the threat of slow economic growth, and social pressure for a better income distribution." 40

Internationally there were events that further complicated Betancourt's problems at home. President Eisenhower had imposed a mandatory control on oil imports to the United States. This unilateral measure taken in 1959, clearly reflects the dominant nature of the U.S. capitalist expansion. In this case, cuts were imposed on Venezuela's oil quota without any regard for the serious damage they would inflict to Venezuela's oil revenues, and consequently, to Venezuela's economy. The following year, 1960, the Betancourt government faced a new problem, overproduction in the world oil had caused a glut, the price of oil fell and consequently, Venezuela's oil revenues further declined. All this resulted in a $\$ 150$ million reduction in annual income for Betancourt's government. 41 This economic crisis, 
which had been prompted in large measure by the United States, forced Betancourt not only to use a $\$ 200$ million loan he had just negotiated with U.S. banks, but also to begin looking for more money from the United States in order to overcome the crisis and run his government's programs, all a reaffirmation of Venezuelan dependence on the United States.

Regarding the decline in world oil prices, it is important to make brief reference to "posted pricing," and how it affected Venezuela. Posted pricing refers to the price the oil companies fixed for oil in the international market. Before the world oversupply of oil became evident, posted pricing was relatively high, and as a consequence, Venezuela was able to get a larger share of the oil income. After the oil glut, however, the oil companies no longer control posted pricing, so prices dropped and Venezuela's income was drastically reduced. The result was that the country was caught in an economic crisis which compelled Betancourt to seek negotiations with fellow oil producing nations in the Middle East. The purpose was to form an international oil organization that would regulate world oil production and thus prevent the posted price of oil from falling.

From the above, it is clear that the U.S. capitalist expansion and the oversupply of oil in the world, 
inadvertently stimulated Venezuela's initiative to form an international organization that would allow Venezuela to get a fairer share for its oil resource. That is indeed one of the factors that explain OPEC's birth.

It could be argued that in seeking to form OPEC, Betancourt may have overlooked the Betancourt Doctrine as he engaged in negotiations and mutual collaboration with nondemocratic governments in the Middle East. It must be remembered, however, that the Betancourt Doctrine exclusively applied to non-democratic or dictatorial regimes in the Western Hemisphere. Those were regimes that, by reason of their ideological differences and geographical proximity could threaten Betancourt's government. In the end, Betancourt's actions may have contradicted the Betancourt Doctrine, but he was adhering to populist logic in wanting to participate in OPEC.

The point here, therefore, is that OPEC really goes along with Betancourt's and $\mathrm{AD}^{\prime}$ 's populist logic. One of the main traits of populism is that of social justice. 42 Accordingly, social justice is called for in those situations in which one class, for reasons of material wealth or status unfairly dominates or exploits another. Thus, in order to remedy this unfair condition, the oppressed class unites in a common effort to demand, through social justice, better treatment from the dominant class. 
Transferring this idea to the international area, it becomes obvious that to Betancourt, there were unequal conditions governing relations between underdeveloped oil producing nations, and developed oil consuming states. Through OPEC therefore, the underdeveloped oil producing nations could somewhat level up the relationship, by extracting greater benefits from their resources, and by imposing greater duties on the wealthier states. Betancourt's own words illustrate the foregoing argument:

"The defense of the prices for the raw material we produce is an historical exigency... [OPEC] if properly oriented, should be a new example of the politics

Another major trait of populism, one that also reflects the populist nature of OPEC is that the state takes control over a country's natural resources. According to populist logic, the state is responsible for centralized planning, and for channeling a country's human and natural resources as a means of bringing about the economic transformation and progress of nations. Betancourt therefore believed OPEC to be a means for channeling Venezuela's and the OPEC countries' oil resources and, through a concerted effort, increase oil revenues for the greater benefit of their people. As Betancourt himself stated: 
"We are united by the common interest of unifying efforts and joining the will to extract the black juice from our soils for the greater benefit of our

Thus, through OPEC, Betancourt sought to improve Venezuela's economic relations with industrialized countries, especially, the United States. He furthermore tried to establish a more direct and equal relationship, as Hellinger states, a "special relationship," between his government and the United States. 45

\section{CONCLUSION}

An analysis of Venezuela's foreign policy during the period of the Betancourt Doctrine has demonstrated that foreign policy was determined by U.S. pressure as well as by Betancourt's desire to protect his position and power rather than by any inexorable adherence to an ideology. Betancourt needed good relations with the United States because Venezuela's economic welfare depended upon oil and upon a mostly American controlled oil industry. Also, U.S. pressure on Betancourt urged him to remain an all-out supporter of United States anti-Castro policies. Betancourt needed desperately to overcome an economic crisis to maintain his hold on the government. The United States, then, provided him with the means to stay in power, by increasing foreign investments and foreign grants and 
credits to Venezuela. Finally, the combination of U.S. capitalist expansion and Venezuela's domestic economic problems, forced Betancourt to seek negotiations and collaboration with countries in the Arab World to form an organization that would control oil production and allow its members to gain greater benefits from their oil resource. This initiative to participate in OPEC was the result of Betancourt's and $A D^{\prime} s$ populist logic. 


\section{CHAPTER III}

\section{VENEZUELA'S FOREIGN POLICY DURING THE \\ PERIOD OF CALDERA'S IDEOLOGICAL PLURALISM}

This chapter seeks to demonstrate that the foreign policy of Rafael Caldera's administration (1969-1974) can be explained in terms of Venezuela's pursuit of domestic and regional economic goals. It will be argued that the Christian Democrats' major tenets, Ideological Pluralism and International Social Justice had only minimal impact in determining Venezuela's foreign policy and that foreign policy goals were really driven by the desire to expand the country's economic power and regional influence. This chapter seeks also to demonstrate that Caldera's foreign policy was to a considerable extent determined by the economic and political influence of the United States in the hemisphere.

Caldera's COPEI was popularly elected to power in 1969 in large measure as a consequence of the coalition pact formed with Acción Democratica ( $A D$ ) and Unión Republicana Democrática (URD) ten years earlier. According to the terms of the pact the three parties agreed to abide by election results, uphold the Constitution and to share cabinet positions. The main objective of the Punto Fijo Pact (1958) was to strengthen the civilian democratic government that was going to take over a country that had historically been ruled by military dictatorships of the right. Thus, after 
winning the elections, the Betancourt government proceeded to share cabinet positions, demonstrated by the fact that nine of the fifteen cabinet positions were equally divided between $A D, C O P E I$, and URD, and the remaining six were occupied by independents. This pact was crucial in strengthening the democratic trend that would allow COPEI to assume the presidency of Venezuela ten years later.

Ideological Pluralism and International Social Justice became the hallmark of Caldera's foreign policy, thus providing an opportunity to observe the relative importance of ideology in determining the actions of Christian Democrats. Ideological Pluralism emphasizes unity among the Latin American and Caribbean nations regardless of ideological differences, or as Caldera himself calls it, "unity within diversity."1 Eduardo Frei Montalva (Chile's former president 1964-1970), referring to the pluralistic nature of Christian Democracy, stated that it stands neither to the right nor to the left, but with the people in their struggle for justice. ${ }^{2}$

International Social Justice, on the other hand, calls for the rich and developed nations of the world to assist, through a sharing of their material and intellectual wealth, in the development of poor states. This International Social Justice must be compatible with: 
"... principles of cooperation, free access to the sources of wealth ... and the application of the principles ... that imply the defense of the weakest in international economic relations." 3

Taken in the context of Venezuela's relations with other countries, especially those of the industrialized world, this principle implies that Venezuela must struggle to attain fair prices for its primary products.

In order to delve deeper into the analysis of Caldera's foreign policy the following questions must be addressed: Does a shift occur in Venezuela's foreign policy after 1969, and if so, what prompts it? How do developments in the domestic and international environment interact and/or influence Venezuela's foreign policy? Was it adherence to COPEI's ideology that determined Caldera's foreign policy or was it pure pragmatic considerations?

During the decade prior to Caldera coming to power, Venezuela's foreign policy was dominated by the Betancourt Doctrine. In conformity with that doctrine, Venezuela denied recognition to dictatorial regimes and in general to regimes established by force. There were many factors influencing Venezuela's promulgation of the Betancourt Doctrine; among them, was a fear that rebellious groups assisted from the outside might endanger the survival of Be- 
tancourt's government. Cuba's shift toward Communism further complicated Venezuela's problems because now the threat was not only to Venezuela's political system but to its capitalist economic system as well. Thus, considerations about the security of Betancourt's government, economic interests and others, forced the Venezuelan president to apply the Betancourt Doctrine and to adopt an uncompromising position toward the few dictatorships in the region. The purpose was to subject dictatorships to economic and political isolation in order to discourage their growth.

When Caldera came to power in 1969 the reality of the regional environment had changed. Practical considerations led him to relinquish the Betancourt Doctrine and adopt a position that could allow him to deal more effectively with the new conditions in the region. The following factors may help explain the shift in Venezuelan foreign policy after 1969 .

1. Predominance of Dictatorial Regimes in the Region

There was indeed a change in regime types in Latin America and this was one of the factors that prompted Caldera to chart a new course for the foreign policy of Venezuela. When Betancourt was in power and the Betancourt Doctrine was applied, there was a wave of civilian liberal democratic regimes in the hemisphere; therefore, Venezuela could afford to suspend relations with the few existent dic- 
tatorships in the region. By the time Caldera attained power, however, most of Latin America was ruled by dictatorial military regimes of the right. Caldera's Venezuela could no longer stand alone against regimes such as Brazil, Argentina, Chile, and Uruguay. This regime-type shift was a decisive factor in conditioning the Venezuelan Christian Democrat's foreign policy. Latin America was experiencing a trend in which even a country like chile, long believed to be one of the most democratic in the hemisphere, succumbed to a military coup. The military now saw itself as a permanent and legitimate solution to the problem of political and economic development in the region. The implication is that if Caldera had continued the policy of non-recognition of de facto regimes he would have dangerously isolated Venezuela from the rest of the countries because he would have to have suspended economic and diplomatic relations with most states in the hemisphere. This thought was conveyed in Caldera's inaugural speech of March 1969:

"We will maintain diplomatic and commercial relations with all countries, independent of the political orientation of their internal regime... for their presence in the world and their influence "in economic relations cannot be ignored." 4

After assuming the presidency Caldera proceeded to renew relations with such diverse regimes as that of Ovando in 
Bolivia, Velasco Alvarado in Peru, Allende in Chile, Stroessner in Paraguay, and Castro in Cuba with whom relations gradually improved.

One of the rationales behind Caldera's foreign policy, again, was that if he had emphasized ideological differences as a mean to sever relations with dictatorial right and/or left wing regimes, he would have deprived Venezuela of potential economic partners and therefore of possible new sources of revenues. Caldera's COPEI, then, sought to increase the country's economic power and its regional influence, and in order to do so the Venezuelan Christian Democrats considered it propitious to maintain diplomatic and economic relations with the great majority of states in the hemisphere, regardless of the internal orientation of their regime. That is how, through Ideological Pluralism, democratic Venezuela not only justified pursuing relations with non-democratic governments but also, as George Grayson points out, through "its aggressive advocacy of ideological pluralism, the Caracas government sees itself playing an increasingly important leadership role among the developing nations." 5

Also, through Ideological Pluralism, Caldera hoped to ease the tensions created by the Betancourt Doctrine between Venezuela and regional left and right wing regimes. Caldera witnessed the many problems brought upon Betancourt's gov- 
ernment by the hatred and rage of Latin American dictators who inspired and supported terrorist activities against Betancourt. Thus, by preaching Ideological Pluralism or "unity within diversity" Caldera sought to convey this sentiment: Let every one govern within his own borders. In support of this point Charles Ameringer argues that as further underpinning for his policy of pluralistic solidarity, Caldera made an earnest request for respect for the principles of self-determination of peoples and non-intervention. 6 Another important factor that must be considered as one influencing the foreign policy of Caldera was domestic, namely that internal democracy was being steadily consolidated. It must be recalled that one of the reasons for $\mathrm{Be}-$ tancourt not dealing with right or left wing dictators was that he feared that the young Venezuelan democracy could be easily threatened by ideologically different regimes. By the time Caldera attained power, however, Venezuela's democracy was consolidated, largely because it was a carefully pacted one. The pact achieved between the three major political forces in the country ensured the continuation of civilian governments and discouraged military intervention. This may then explain why Caldera did not fear the domestic repercussion of entering relations with regimes of different ideological inclination, and moreover, tells something about 
the impact of domestic factors in conditioning foreign policy.

In conclusion, the changes in Venezuela's foreign policy after 1969 can be explained in terms of Caldera's need to adjust to a new set of international political and economic realities. The regime-type shift experienced in Latin America was a factor that forced the Venezuelan president to abandon the anti-dictatorial doctrine of his predecessor and seek relations with the military men holding power in most Latin American nations. Caldera's foreign policy was conditioned also by domestic considerations such as his considered conviction about democratic consolidation in Venezuela. Democratic consolidation in Venezuela was linked to tolerance for authoritarian regimes in the sense that the country's democracy, a carefully pacted one, was believed to be consolidated and therefore free from any form of internal or external militarily-inspired influence, and free to deal with all countries regardless of their type of government.

2. Commitment to Expand Economic Power and Regional Influence Through Wealth.

Some of Venezuela's regional initiatives may help explain Caldera's foreign policy and the shift that occurred after 1969. In this regard three factors will be analyzed:

a. Defense of oil prices.

b. Interest in the Caribbean. 
c. The Andean Common Market or Andean Pact.

a. Defense of Oil Prices.

The oil issue as well as many other crucial issues of the Venezuelan Christian Democrats' foreign policy were rationalized in terms of Internal Social Justice. The central idea was to unite with other lesser developed countries in order to provide an economic front to contend with the industrialized states. Furthermore, International Social Justice meant to Caldera and to COPEI that they must struggle to gain fair prices for Venezuela's raw materials, specifically oil. Therefore, when Venezuela and OPEC encouraged a rise in oil prices they were of the opinion that such a move was in accordance with the proposed wealth redistribution advocated by International Social Justice. As stated by Martz and Myers:

"The Social Christians were ... insistent $\ldots$ that oil earnings must contribute to distributive justice ... [they] encouraged global conditions that might assure ... fair prices."

Also, speaking before the U.S. Congress during his visit to the United States on June 3, 1970, President Caldera had the opportunity to emphasize the relationship between International Social Justice and the defense of the prices of less developed countries' raw materials. President Caldera is reported to have said: 
"I believe in international social justice ... the formula for achieving cordial relations ... cannot be the merciless attempts at forever lowering the prices of our goods." 8

In the end, in trying to explain the impact of International Social Justice on the regime's foreign policy the most relevant point is that the administration tried to seek an accommodation of ideological tenets with economic reality. President Caldera was urged to extract maximum benefit from the oil resource in order to increase Venezuela's economic power.

b. Interest in the Caribbean.

Discussion of Venezuela's new interest in the Caribbean is relevant because it helps explain how Caldera's foreign policy was shaped by Venezuela's desire to expand its power and influence in the region. Venezuela's perception of the Caribbean changed after 1969 mostly in response to the new economic and political reality of the region. The region began to be regarded as vital to Venezuela's national security and economic interests. An area where the country's newly acquired oil wealth could be put to work in order to enhance its economic and political influence in the region. As seen in Table 6, by the beginning of the 1970's, oil prices raised considerably and Venezuela's oil revenues dramatically increased. Table 6 also shows the impact of the 
oil-price increase on the Caldera government's revenues in relation to those of Betancourt.

\begin{tabular}{|c|c|c|c|c|}
\hline & $\begin{array}{l}\text { TAB } \\
\text { IMPACT OF OIL-PRI } \\
\text { CALDERA GOVERN } \\
\text { IN RELATION TO T }\end{array}$ & $\begin{array}{l} \\
\text { UCREASE } \\
\text { S REVEN } \\
\text { OF BETAN }\end{array}$ & & \\
\hline & $\begin{array}{l}\text { (A) } \\
\text { Population } \\
\text { in } \\
\text { Mil. }\end{array}$ & $\begin{array}{l}\text { (B) } \\
\text { Fiscal } \\
\text { Income } \\
\text { in } \\
\text { Mil.Bs. }\end{array}$ & $\begin{array}{l}\text { (C) } \\
\text { Crude's } \\
\text { Price } \\
\$ \text { per } \\
\text { Barrel }\end{array}$ & $\begin{array}{l}(D) \\
\text { Income } \\
\text { from } \\
\text { oil }\end{array}$ \\
\hline $\begin{array}{l}\text { Betancourt } \\
1959-63\end{array}$ & $8.0 \mathrm{Mil}$. & 16,285 & 2.98 & Bs. $2,036.00$ \\
\hline $\begin{array}{l}\text { Caldera } \\
1969-73\end{array}$ & $12.0 \mathrm{Mil}$. & 36,952 & $\begin{array}{c}5.80 \\
\text { (Raised } \\
\text { to } 9.91 \\
\text { in Sep } \\
1973\end{array}$ & Bs. $3,079.00$ \\
\hline
\end{tabular}

One of the many factors determining Caldera's foreign policy toward the Caribbean, and certainly one of the most important, was his desire to enhance Venezuela's regional influence. Judith Ewell supports this point when she affirms that, because of its population size, geographical extension and oil wealth, Venezuela had the potential for a much greater regional influence than the multitude of small Caribbean states, and therefore its influence and active role could easily be extended. ${ }^{9}$ Evidence of Venezuela's regional interest can be seen in the fact that it was the 
first non-English speaking nation to become a member of the Caribbean Development Bank which was a lending agency for the Caribbean Commonwealth. In its first year of membership Venezuela contributed $\$ 13$ million to the bank. 10 Interest in the region also showed in the number of loans given to individual states and in the proliferation of Venezuelan banks and investments. Boersner argues that after Caldera initiated the thrust toward the Caribbean, Venezuela's industrial bourgeoisie began to look overseas for markets.11 Venezuela's commitment to expand its Caribbean influence was also reflected in the tremendous promotion of tourism launched by the government within and outside the country. The New York Times noted that advertising to promote tourist activities identified the country prior to 1969 as the front door to South America, and now described it as "the country in the Caribbean."12 Indeed, as Martz states:

"Such Venezuelan activities typified its decision to enter the English-speaking Caribbean, where commercial ties had historically been weak." 13

Another reason for increasing Venezuela's role in the Caribbean was that the COPEI government feared Brazilian economic regional influence. The beginning of the 1970 s was a period that witnessed the so-called Brazilian economic miracle. Accordingly, due to economic growth and political stability, Brazil seemed to be awakening to a new era, and 
its public and private investments dramatically increased throughout the region. As this occurred, Venezuelan concern over Brazilian regional expansion began to grow. It was, then, within this context that Caldera initiated a more active Venezuelan regional role. Grayson refers to this Venezuelan growing concern: "Venezuela ... moved vigorously ... to check Brazilian influence and exert her own in the Caribbean."14 Bond stresses the same point:

"Calvani (Caldera's Foreign Minister) feared Brazilian expansionism, and apparently believed that Brazil desired to extend its influence toward the

Accordingly, Venezuela initiated a period of intense negotiations with the Anglophone and Hispanophone Caribbean as well. One of the most important achievements was the institutionalization of relations with the Caribbean as reflected in the various conferences held by foreign ministers of Venezuela and their counterparts in the rest of the Caribbean.16 There seems to be reason to believe that Venezuela was successful in its design to disguise the real intention of its Caribbean thrust with its emphasis on Ideological Pluralism and International Social Justice. Perhaps one of the exceptions was Trinidad Tobago's Prime Minister Eric Williams, who accused Venezuela of seeking to recolonize the Caribbean. 17 
Williams' perception of Venezuela of course was not unfounded. Venezuela's newly found oil wealth was being channelled toward the Caribbean and Caldera's government was committed to extract maximum benefits from this relationship. Venezuela's desire for domination was clearly expressed not only by government officials but also by the most refined Venezuelan students of geopolitics. For example, Ruben Carpio Castillo acknowledged that geographic factors and natural wealth could give "Venezuela greater power in the possible formation of a Caribbean Federation."18 Obviously, such a statement supports the idea that venezuela desired to dominate the region, and fuels any suspicion that it intended to do so. Williams' perception of Venezuela's desire for regional supremacy was reinforced by the fact that by the beginning of the 1970s, Venezuela did not have to face the European powers' colonial outposts in the Caribbean, but instead a group of small, relatively weak, newly independent states.

Ironically, Williams himself wanted to assume regional leadership but he found in the Latin country a more powerful competitor. Venezuela's oil wealth far exceeded that of Trinidad's which allowed Caldera's Venezuela to enhance its means for capitalist penetration and influence in the region. 
In the end, Caldera's government was rhetorically trying to show that its country was motivated by the search for unity among regional countries, and by the desire to contribute to the development of these countries through Ideological Pluralism and International Social Justice. Facts brought out here, however, demonstrate that venezuela was instead trying to emerge as a "semi-peripheral" nation. As already shown, the desire to increase Venezuela's regional influence, as well as fear of Brazilian expansionism, were among the factors that dictated the foreign policy of Caldera's Christian Democratic party during the years 19691974 .

C. The Andean Common Market or Andean Pact.

Venezuela's decision to join the Andean Common Market (originally made up of Bolivia, Colombia, Chile, Ecuador and Peru) in February 1973 reflects the COPEI government's desire to increase Venezuelan regional influence. There were political and economic reasons that prompted Venezuela to enter in the Andean Common Market or Andean Pact: First, the desire to increase Venezuela's economic power and the need to diversify the economy. Secondly, the commitment to counteract Brazilian and U.S. regional domination. It is in this context that the Caldera government pursued political and economic interests in the name of Ideological Pluralism and International Social Justice, by committing itself to 
having relations with as many Latin American and Caribbean countries as possible. Evidently, relations with Marxist Chile or Bolivia's rightist dictatorship would have been impossible had the Caldera government discriminated on the basis of ideology.

The primary focus of the government, then, was to broaden the number of Venezuela's trade and economic partners, hoping that by gaining access to the markets of the Andean Pact members, Venezuela's economic power would be increased. In contrast to the rest of the Pact's members, by the time she joined the Common Market, Venezuela was experiencing a consistent growth rate, a stable currency and a readily available supply of capital. This made it possible for Venezuela to penetrate the other countries' economies and by means of its economic power create spheres of influence. As Robert D. Bond points out, "Venezuela's actions in several sub-regions aroused suspicions that it was trying to carve out spheres of influence."19 when Venezuela joined the Andean Pact, then, it had the opportunity to put to work the millions in extra revenue derived from increased oil prices. Venezuela contributed $\$ 60$ million to the Corporación Andina de Fomento, an agency established to serve as financial agent for Andean Pact members. 20

Interest in joining the Andean Common Market was stimulated also by the fact that Venezuela's economy, largely 
based on income from petroleum, needed to diversify. During the years Caldera was in power, for example, the oil industry provided $93 \%$ of the country's foreign exchange and more than $70 \%$ of its budget. 21 With such heavy dependence on oil the country's economy was doomed to collapse when oil reserves were depleted. Thus, Caldera's government considered it expedient to enhance diversification through participation in the pact. In addition to gaining access to new markets, joining the pact would reorient the economy towards diversification. Such a change would not come automatically but now Venezuela was encouraged to produce manufactured and other products for consumption in Andean Pact's markets, thus creating new sources of revenues and consequently diminishing overdependence on oil. Ferris, for example, argues: "domestic economic adversity leads to increase regional cooperation..."22 In summary, the Caldera administration feared the negative effects that an absolute dependence on oil would eventually bring upon the country's economy. It also hoped that by gaining access to new markets it would not only have new sources of revenue, but would also encourage diversification as new products from Venezuela began to be sold in the Andean States.

The second part of the argument has to do with Brazilian and U.S. regional domination. Ewell asserts that in deciding to join the Common Market, Caldera assumed that the 
Spanish-speaking nations of Latin America had to combine forces if they were to keep Brazilian economic expansion under control.23 Ewell's argument falls in line with the logic of the Economic Commission for Latin America (ECLA), and Latin American populism whose focus in on regional integration. The Venezuelan president, then, argued in favor of the Andean Market on economic and security grounds. Evidently he felt he needed to join the Pact in order not only to extend Venezuelan influence in the region but also to check Brazilian regional initiatives. Venezuela's suspicions about Brazil became even greater as the latter proposed the creation of the Amazon Treaty. This treaty, as perceived by Venezuela, was intended to confront the Andean Pact. Moreover, the Brazilian proposal, as Elizabeth Ferris argues, might have been "seeking to coopt the Andean countries by including them in a Brazilian-dominated group." 24 Venezuela became one of the most outspoken critics of Brazilian initiatives in the region and in doing this it achieved some success. Venezuela was committed to not stand aloof from a regional power struggle and strove to enhance its own influence. As stated by Ameringer:

"By the time that Caldera neared the end of his term, he was successfully challenging Brazil and other emerging powers of Latin America for a position of leadership ... He recognized Venezuela's increasing economic power and strove to 
use it to extend the nation's influ-
ence..." 25

It appears obvious then that Caldera's Ideological Pluralism and International Social Justice were simply an ideological façade used to justify a two-power struggle for subregional domination. Venezuela strove to contain the giant Brazil's economic influence while Brazil sought to counteract Venezuela's increased regional power derived from its oil wealth.

Needless to say, Venezuela's initiative to join the Andean Pact was determined also by the hemispheric influence of the United States. This assertion requires a two-fold explanation. First of all, Venezuela became highly suspicious of U.S. favoritism for Brazil as the dominant subregional power. Brazil's geopolitical and economic importance to the United States in the subregion may have contributed to promote more favorable American relations with the giant of the south than with any other country in the region. Among the evidence that demonstrates this U.S. bias in Latin America is an agreement signed between the United States and Brazil in which the Americans gave Brazil the "privilege" to discuss important issues with them twice a year.26 Also, according to the Caracas newspaper EI Nacional, Kissinger's comments regarding Brazil tend to identify the United States 
with that South American country. Accordingly, Kissinger said:

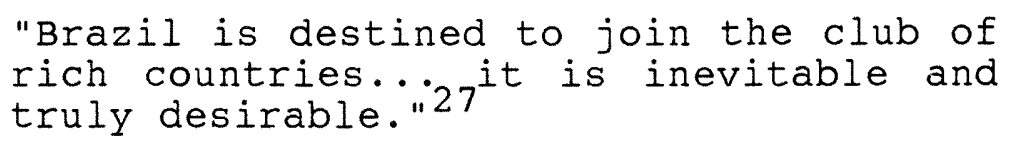

Another rationale for membership, then, was that through the Andean Pact, Venezuela was seeking to promote strong unity among Spanish-speaking Latin American nations in order to counteract United States' favoritism for Brazil.

Also Caldera reasoned that by joining the Andean Pact the members could as a common bloc, demand equal treatment from Washington. On several occasions the Venezuelan president reminded the United States that it was its duty to help the Latin American developing countries achieve their objectives. 28 As demonstrated by Venezuela's encouragement of a rise in oil prices, the Caldera administration believed it was a U.S. obligation to pay higher prices for Venezuelan crude as a means to help this country achieve its goals and as a way to fall in line with the wealth redistribution proposed by International Social Justice. Herman, referring to this issue states:

"The concept not only explained United States obligation toward Venezuela and Latin America, but it also provided a rationale for steps taken to increase Venezuela's economic power, particularly ... increasing the export price of petroleum." 
Finally, Caldera's COPEI realized that though still subject to U.S. hemispheric domination, the common bloc formed through the Andean Pact, would provide for pact members a more advantageous position to confront the United States. Caldera reasoned that what the Americans sought was to divide and manipulate countries individually. That is one of the reasons why Venezuela stressed unity within diversity or Ideological Pluralism in order to oppose the United States as a bloc.

\section{CONCLUSION}

An analysis of the foreign policy of Venezuela during the period of Caldera's Ideological Pluralism can be most profitably understood in terms of Venezuela's pursuit of economic and security goals, rather than in terms of advocacy of an ideological posture. It explains how Christian Democracy's major tenets, Ideological Pluralism and International Social Justice were used as a façade to justify the pursuit of political and economic interests on ideological grounds. This conclusion is supported by Martz: "It would be misleading to maintain that ... Caldera ... was unduly constrained in his policies by ideological blinders ... ideology was merely helpful in rationalizing decisions already made. " 30 
In the hope of increasing the country's economic power the COPEI government initiated a round of intense negotiations with all regional governments regardless of ideological choice of internal regimes. Venezuela's newly found wealth as a result of a dramatic increase in oil prices, provided the means to create spheres of influence in the Caribbean and the Andean region.

Also, fear of Brazilian regional domination prompted the Caldera administration to intensify Venezuela's role in the region. Brazil's power, coupled with the apparent favoritism on the part of the United States, intensified before the relatively individual weakness of the rest of Latin American states. This led Venezuela to seek closer economic and political ties with neighboring Andean countries. In addition, through membership in the Andean Common Market, Venezuela sought to diversify its economy, create new sources of wealth and diminish overdependence on oil revenues.

In the end, Caldera's foreign policy was purely a pragmatic one because it consisted of making practical decisions for the achievement of material goals. COPEI's philosophical tenets did not determine Caldera's foreign policy, but instead it was the new realities of the domestic and regional environment that dictated the course of his foreign policy. Again, Ideological Pluralism and International So- 
cial Justice were just the means to hide the pursuit of national interests which lay behind ideology. As noted by Liss :
"The socialistic party platform of $\ldots$ COPEI has had little influence on the conduct of foreign policy, which has been carried on under the influence of traditional, sometimes liberal, economic capitalism." 31 


\section{CHAPTER IV}

\section{FINDINGS AND CONCLUSIONS}

This concluding chapter is the linking chapter in the present study. It defines the importance of the preceding chapters, and fits chapters two and three into the conceptual frame work of chapter one. This section will also look at the findings of this study and their significance. Finally, some speculative propositions will be made regarding the possibility of applying the present approach to other cases.

We now briefly summarize Betancourt's foreign policy first, followed by Caldera's. As examined in chapter two, the foreign policy of venezuela during the period of the Betancourt Doctrine was not determined by Betancourt's inexorable adherence to democracy but by U.S. pressure and his desire to remain in power. Ideology only had a minor impact on conditioning Venezuela's foreign policy, and it functioned as the means to justify and/or hide the pursuit of political and economic interests rather than as a determinant of foreign policy.

Chapter three showed that when Caldera's COPEI attained power in 1969 it claimed to be firmly committed to international political economy based on the principle "of cooperation, of free access to the sources of wealth for all peo- 
ple, and of the application of social justice. 1" This, however, was only the rationale the Venezuelan Christian Democrats gave to justify their pursuit of regional economic and political interests because Caldera's foreign policy consisted of making practical decisions for the achievement of material goals. COPEI's philosophical tenets, Ideological Pluralism and International Social Justice, did not determine Caldera's foreign policy, but instead it was the new realities of the domestic and regional environment that dictated the course of his foreign policy. Again, ideology was only the means to hide the pursuit of national interests.

In establishing the theoretical linkages and defining the importance of this case study it is seen that the Venezuelan case is linked to the arguments of some theorists. Morganthau, for example, argues that the key concept governing the actions of statesmen in international politics is that of interests defined as power. ${ }^{2}$ Caldera's foreign policy supports Morganthau's remarks. Accordingly, Caldera used Venezuela's oil wealth to penetrate the economies of Caribbean and Andean states to gain some control of the economic decision-making in those countries. In doing that, therefore, Venezuela was accused of wanting to recolonize the region by exerting its economic power. These facts clearly demonstrate that Venezuela's Christian Democrats did not at all reject capitalism on the basis of its exploita- 
tive nature (as stated in Christian Democratic Doctrine) but instead advocated it in pursuing regional foreign policy goals, or as Morganthau would put it, their foreign policy was governed by interests defined in terms of power rather than by any philosophical conviction.

Morganthau argues also that power controls the actions of men in international relations, 3 meaning, of course, that the actions of weak states are constrained and/or driven by the economic, political or military power of the strong ones. This was such in the case of the Betancourt Doctrine because Betancourt's foreign policy was, to a large extent, dictated by the economic power of the United States. Betancourt knew that the survival of his government depended on the protection and promotion of U.S. economic interests in Venezuela, and that U.S. capital expansion was crucial for his political survival. That is why it is not difficult to explain why the Betancourt Doctrine coincided with the U.S. anti-communist struggle in the hemisphere.

Caldera's foreign policy was also conditioned by the power factor referred to by Morganthau. His decision to increase Venezuela's role in the region was significantly determined by the influence that powerful Brazil was beginning to exert in the region. Moreover, Brazil's power, coupled with the apparent favoritism of the United States for Brazil as regional leader, intensified Venezuela's desire to seek 
closer relations with neighboring states, thus revealing how the economic and political power of the United States and Brazil dictated Venezuela's foreign policy.

Cardoso and Faletto contend that relations between states are characterized by a dependent situation in which the state in the dependent nations plays a mediating role between dominant classes in the central or dominating state and the peripheral or dominated state. The state, accordingly, functions as a channel for foreign capital transfer, thus making available foreign resources to the privileged classes. 4 This study has shown that neither AD nor COPEI showed any firm determination to resist U.S. capitalist expansion in Venezuela but instead, they were aware that their economic performance largely depended on U.S. capital inflow. The case of Betancourt, for instance, shows that the amount of U.S. economic aid and U.S. investments in Venezuela was such that it was clear that the Betancourt government remained in large measure alive through the inflow of U.S. money. In this process of capital transfer, the Venezuelan state, headed by Betancourt, served as a mediator between U.S. capital and Venezuela's dominant classes, therefore corroborating Cardoso and Faletto's view regarding the mediating role of the state.

Moreover, the above confirms the contention of dependency theorists who argue that as a result of the ties es- 
tablished between dominant elites in the dependent and dominant countries, the internal and external conditions of the dependent country are effected. The final result of such relationship, they say, is a high degree of agreement between the foreign and domestic policies of a dependent country and the economic, political and security interests of a dominating one. 5 This correlation, emphasized by scholars in the dependency tradition, stands out especially as it conditioned Betancourt's doctrine and his relations with the Urited States.

Regarding the issue of foreign policy and how this is conditioned by other countries, Morganthau states, "It is not enough for a government to marshal national public opinion behind its foreign policies. It must also gain the support of ... other nations ..."6 obviously Morganthau is saying that the foreign policy of a country is conditioned by the degree of support it gets from external actors. Otherwise, the foreign policy may be doomed to failure. The above theorist's hypothesis is substantiated by evidence brought out in this study. The issue of the United States recognition of the Betancourt Doctrine, for example, became crucial to Betancourt if dictatorship were going to be discouraged and isolated. However, failure to get the United States to withhold recognition from such regimes contributed to the weakening of the Betancourt Doctrine and consequently 
to the deposing of Betancourt's $A D$ in 1948. This reflects how failure to get the support of other nations (the United States) contributed to the lack of success of a country's (Venezuela) foreign policy.

Quite to the contrary, support received from Latin American and Caribbean nations allowed the Caldera government to achieve considerable success in accomplishing established regional goals. Ideological Pluralism and International Social Justice, though only an ideological facade, appealed to most states in the hemisphere especially in light of the fact that they all demanded better treatment from the United States.

The present study corroborates Reynolds' argument that action on the part of a one state is constrained by perceived domestic circumstances as well as by the actions of other states, and how the first state perceives other states. 7 He refers to the fact that foreign policy making must take into account the decision-makers' perception of domestic and international factors, and that these will in turn conditions the actions of a state. The case of Betancourt shows how his perception of domestic circumstances and of the United States influenced his foreign policy. When Betancourt applied the Betancourt Doctrine to Castro's Cuba, for example, he was well aware that not to do so would bring economic disaster upon his government since U.S. Aid and in- 
vestments in Venezuela would have stopped. Thus, Betancourt's perception of internal and external circumstances led him to avoid the potential worst consequences in conducting his foreign policy.

Caldera's foreign policy too, was very much conditioned by his perception of domestic circumstances as well as by the actions of other states. As seem before, Brazil's influence in the region was one of the factors that awakened Venezuela's interests in expanding its regional role. The Venezuela Christian Democrats feared that if Venezuela did not become more active in the region, Brazil would be free to exert regional domination, thus threatening Venezuela's overdependence on oil for revenues was another factor that constrained him to take a certain course of action in his foreign policy. Awareness concerning this fact led him to seek membership in the Andean Common Market which would give Venezuela the opportunity to produce new products for consumption in Andean states. This would in turn initiate a degree of economic diversification, thus diminishing overdependence on oil and creating new sources of revenue. It is obvious, then, that Venezuela's foreign policy was indeed conditioned by the actions of other states as well as by Venezuelan leaders' perception of those other states and their perception of domestic circumstances. 
A well known factor, brought out again in this study, is that foreign policy is not made in a vacuum, meaning that in analyzing foreign policy, domestic and international as well as economic and political factors must be considered. Blake and walters point out the rather obvious fact that a complete understanding of global relations cannot be attained unless the necessary linkages between the aforementioned factors are established. ${ }^{8}$ In the cases of the Betancourt Doctrine and Caldera's Ideological Pluralism the present study has shown that these were indeed conditioned by the interconnection referred to by Blake and Walters. Bentancourt, for instance, first considered the repercussions that an internation political factor such as U.S. anti-communist policies could bring upon his domestic economic and political issues. Then he became an all-out supporter of U.S. policies in the hemisphere. Caldera's Caribbean and Andean thrust, for its part, was initiated after he gave due consideration to the domestic economic and political impact that such external factor as Brazilian regional influence could bring. Thus, it is seen how these various sets of interrelationships between economic, political, domestic and international factors conditioned and/or limited Betancourt and Caldera's foreign policy actions.

In agreement with Blake and Walters, this contends that Venezuela's domestic welfare depends on the country's in- 
ternational economic relations, and that its foreign policy is more than ever influenced by the oil industry. ${ }^{9}$ This argument is in direct correlation with the present thesis. Findings brought out here showed how Venezuela's overdependence on a mostly American-dominated oil industry conditioned Betancourt's foreign policy toward the United states. Also, this study has demonstrated that Caldera's foreign policy was closely linked to the oil issue because the increased revenue, generated as a result of a rise in oil prices, served to support the Venezuelan Christian Democrats' Caribbean and Andean commitments.

Tugwell, for his part, points out that oil politics in Venezuela have come to operate as an independent variable in regard to most other policy-making areas. 10 This statement is confirmed by what has been said of Venezuela during the periods of Betancourt and Caldera's rule. Oil was so important to them that its influence on their foreign policies could hardly be overstated.

There are some foreign policy theorists who argue that in examining the most important factors that condition foreign policy one cannot ignore the role of certain societal or domestic issues. Rosenau, for example, states that there are domestic forces such as the press, economic groups, parties and others whose role in determining foreign policy is not less important than the external forces toward which the 
foreign policy is intended to be directed.11 This contention is fully supported by the present study because the Betancourt Doctrine and Caldera's Ideological Pluralism were to a considerable degree made possible by the support received from opposition parties, privileged economic groups, etc. There can be little doubt that Betancourt and Caldera could ever have attained power, let alone carry out their foreign policies, without the role of such a crucial domestic factor as party support or the mutual support achieved between Acción Democrática, Copei and Union Republicana Democrática (URD). The 1958 Pact of Punto Fijo was the highlight of this mutual collaboration. This coalition not only allowed Betancourt's AD to come to power in 1959 to implement the Betancourt Doctrine, but it also paved the way for the continuation of a civilian government that would later allow Caldera and his Ideological Pluralism to perform from the presidential seat. The Punto Fijo Pact, then, supports the argument regarding the important role of domestic forces in shaping foreign policy.

K. London supports the idea that there are basic factors such as a nation's physical, political, economic and military conditions that must not be ignored in making foreign policy. These, he terms, national attributes. ${ }^{12}$ obviously London means that these factors can determine the limits or the range of statesmen in formulating foreign policy 
and therefore in planning their course of action. Statesmen, accordingly, are limited by their available resources but they can convert these into the main force behind their foreign policy decisions. The Betancourt Doctrine reflects the influence that some of these national attributes or national economic and political conditions mentioned by London had upon that doctrine. Economically, Betancourt needed the assistance of U.S. capital to get the country out of the economic difficulties it was in. He, then, strove to shape his foreign policy in agreement with Washington's to obtain American economic help. Politically, the effects of the economic crisis and the fact that the Betancourt government was so young, coupled with the threat of a military takeover, moved Betancourt to stay with the United States and simultaneously to suspend relations with all dictatorial regimes in the hemisphere for fear that these might influence his government and threaten his position and power. These findings obviously reflect how the consideration of domestic political and economic conditions affected the foreign policy of Venezuela.

Caldera's foreign policy too, substantiates London's contention regarding the role of national attributes in shaping foreign policy. Venezuela's Christian Democrats believed that due to its size, economic power and political stability, Venezuela was capable of making an impact on the 
region, and this they were determined to accomplish. The small size and economic weakness of the conglomerate of Caribbean states, and the economic and political problems plaguing the Andean countries enhanced Caldera's confidence and his determination to play an active role in both areas. Therefore, he resolutely launched his regional thrust as an attempt to use Venezuela's "national attributes" in pursuing his foreign policy goals. This confirms the contention that statesmen can convert their available resources into the main force behind their foreign policies.

According to Millar much of a country's foreign policy is inherited, meaning that history and events are among the most important factors that condition foreign policy.13 Millar's view relates to that of Lowi in that past events and experiences not only shape foreign policy but they help contribute to produce a different type of leadership. ${ }^{14}$ This study showed how Venezuela's long history of dictatorships shaped a new type of democratic leadership and consequently of foreign policy. Historically, the Venezuelan state had been regarded as private property by the military dictators who hold power. Foreign policy, then was geared to protect and increase the assets of the dictator in power and not necessarily those of the country. However, technology, newly-found riches and political discontent called for a change, beginning about a new system dominated by civilian 
leadership such as that of Bentancourt and Caldera. This new leadership type, brought in turn a reorientation in Venezuela's foreign policy, now geared to promote political changes and populist reforms. It is seen, then, how the country's past history and events shaped the emergence of a distinctive type of leadership and foreign policy.

Frankel, for his part, argues that there is an "irner element" that is crucial in the determination of foreign policy and defines "inner element" as the ideologies, beliefs and values that may influence statesmen in formulating their foreign policies. ${ }^{15}$ The present study however, shows that ideology had very little impact in the determination of Venezuela's foreign policy, and that it functioned only as a means to rationalize practical decisions already made. In the case of Betancourt, for example, we have found that the Betancourt Doctrine was motivated by his desire to gain U.S. economic and political support, and by his commitment to remain in power. Needless to say. Betancourt's decision to not deal with dictatorial military regimes of the right or left was not determined by his inexorable commitment to democratic ideals, but by his desire to protect his hold on power.

It was only in the case of OPEC that this study revealed a connection between Betancourt and Acción Democratica's populist logic and foreign policy. Accordingly, two 
of the major tenets of populism, social justice and statecontrolled natural resources, influenced the Betancourt administration to seek negotiations with other oil producers in the Arab Worlds. These moves demonstrated the Venezuelan government's desire to enhance the country's possibilities to get fairer returns for its oil resources, and in that way bring a more equal relationship between the have nots (Venezuela) and the haves (United States and other industrialized countries.) The move toward the formation of OPEC also demonstrated Betancourt's populism as he tried to increase state control and management of Venezuela's natural resources.

In the case of Caldera, the present study has shown that the major priority of Caldera and COPEI's foreign policy was to check Brazilian sway and increase Venezuelan economic and political influence in the region. They were committed to accomplish regional goals, that is, expand Venezuela's role in the Caribbean and the Andean regions through the use of oil wealth. In doing this, then the Venezuelan leaders hoped not only to gain access to the markets of those countries in the region with which they became involved bur also to diversify the country's economy as Venezuela began to produce new products to be sold in the Caribbean and Andean regions. Obviously, this diversifica- 
tion would diminish Venezuela's overdependence on oil for revenues.

The research conducted for this study supports the findings of theorists such as London, Morganthau, Marx and others who argue that ideology is just an artificial or superficial appearance used to hide the real intentions driving statesmen in the formation of domestic and foreign policies. London states that ideology is used to justify policies and actions but that these are not shaped by ideology. 16 Ideologies for Morganthau are no more than disguises used to hide the pursuit of sel-interests and power. ${ }^{17}$ Marx argues that ideologies only exist to maintain the ends and purposes of the dominant classes.18 It is obvious, then, that Marx's view on ideology relates to that of Morgenthau's in the sense that they both acknowledge that ideologies are used to seek, keep, and justify power. Taking these theoretical assumptions in the context of the findings of this study, it is clear that the Betancourt Doctrine and Caldera's Ideological Pluralism and International Social Justice were only the ideological frame works used to hide, rationalize and justify Venezuela's foreign policy goals. Without this ideological disguise, Betancourt would have been perceived as one selling out the country to U.S. capitalist interests, while Caldera would have appeared as one wanting, as Williams said, to recolonize the region. 
These findings clearly corroborate the argument that statesmen are not driven by ideologies in pursuing their policies but instead by practical considerations. They tend to refute therefore the contention that a leader's beliefs are of predominant importance when he develops his foreign policy.

Thus, there is evidence in support of this study's initial hypothesis that the foreign policy of Betancourt was not determined by ideology but by the domination of the United States in the Western hemisphere, and by Betancourt's commitment to improve Venezuela's economic condition as a means for him to remain in power. Also, it was corroborated that Betancourt sought to take the best possible advantage of the dependent situation he was in under U.S. capitalist expansionism. Evidence brought out in this study seems to demonstrate, too, that Caldera's commitment to expand Venezuela's regional influence and economic power through wealth, determined his foreign policy. Ideology, then, was for Caldera as well as for Betancourt a rationalization for decisions already made.

The findings of this study support most of the theoretical assumptions discussed in the initial chapter. Only in few cases have the contentions of theorists been refuted by the investigation and conclusions arrived at in the present study . 
What is the importance of these findings and how can they be applied to other cases? It seems appropriate to say that under the unequal international economic system that presently operates, it is very likely that the foreign policies of less-developed states will be greatly conditioned, restrained and/or compelled by the dominating influence of powerful, more-developed states. This unequal relationship nurtures and perpetuates a dependent situation in which the foreign policies of the weakest states is in most cases in direct correlation with the economic, political and security interests of the strongest nations. Only radical detours from the established order or status-quo seem to give developing countries a somewhat more independent path, but in doing this, less-developed states tend to suffer because concomitant with their shift away from a powerful nation's domination is the loss of economic support from the same.

Another factor that seems certain is that less-developed states will use all kinds of rhetoric and ideologies to justify dependence and/or to contend against the unfair comination to which they are subject. The Betancourt Doctrine and Caldera's Ideological Pluralism and International Social Justice are a clear reflection of this dichotomy. The former tried to justify dependence on the United States while the latter strove to contend against that dependence for the sake of economic equality. Needless to say, claims on the 
part of the have-nots are only rhetoric and a means to achieve goals because as Morganthau argues, all nations are engaged in a struggle for power, and even their ideological rhetoric is defined in terms of power. Ideological pluralism and International Social Justice, for example, gave Venezuela a voice to contend against the unfair economic domination of the outside industrialized world while she simultaneously practiced regional economic domination.

It is important, therefore, in studying the foreign policies of states that the analyst avoid the misleading assumption that the foreign policies of statesmen are derived from their ideological beliefs. Ideology has indeed very little impact in determining the course of a nation's international behavior, but its use serves two purposes: to gain the support of domestic public opinion, and justification before the public opinion of other nations.

A factor that seems to play a determinant role in conditioning foreign policy is the link that exists between domestic and external forces. It would be a mistake to believe that international affairs are eclipsed by domestic issues in formulating foreign policy, or vice versa. External concerns appear to affect foreign policy makers in charting a course for their countries in the international milieu. Also, foreign policy seems largely conditioned by the domestic economic, social and political circumstances 
prevailing in a country. The success, therefore, of foreign policy depends on how well statesmen take into account both factors in formulating foreign policy.

Finally, the foreign policy of dependent states like Venezuela is not doctrinal but pragmatic. No matter how much ideological rhetoric they use, their positions are always open to changes and conciliations, all according to the dictates of the international economic system to which they are subject. There appears to be, then, an obvious correlation between the foreign policies of dominated states and the interests of powerful transnational capital.

It is important to emphasize, however, the limitations of the present study, and to acknowledge that some of the conclusions are subject to revision. The author believes the conclusion to be acceptable but subject to further verification and research. There is indeed a real possibility of applying the present approach to other cases, especially to those cases like that of Venezuela where a dependent situation predominates. Therefore, the writer believes that the generalizations and conclusions in the present study are consistent with the international behavior of states in their developing stage. 


\section{FOOTNOTES}

Chapter one

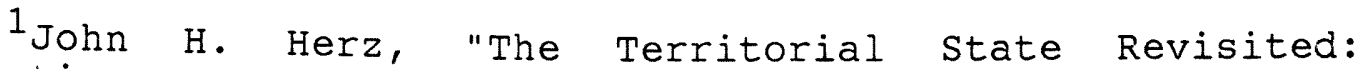
Reflections on the Future of the Nation state," in International Politics and Foreign Policy, ed. James $N$. Rossenau (New York: The Free Press, 1969), p. 76.

2 Lester Pearson, Democracy in World Politics, (New York: Oxford University Press, 1956), p. 40.

3 Joseph Frankel, The Making of Foreign Policy, (London: Oxford University Press, 1963), p. 1.

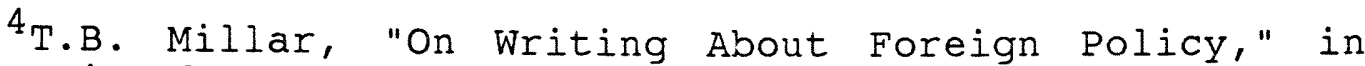
International Politics and Foreign Policy, ed. James $N$. Rossenau, p. 57.

${ }^{5}$ P.A. Reynolds, An Introduction to International Relations, (New York: Longman Inc., 1980), p. 51.

${ }^{6}$ Kurt London, The Making of Foreign Policy, East and West, (New York: J.B. Lippincott Company, 1965), p. 54.

${ }^{7}$ Hans J. Morgenthau, Politics Among Nations, (New York: Alfred A. Knopf, Inc., 1967), p. 5.

${ }^{8}$ Ibid., p. 143.

${ }^{9}$ James N. Rossenau, Domestic Sources of Foreign Policy, (New York: Free Press, 1967), pp. 3-4.

${ }^{10}$ London, The Making of Foreign Policy, p. 20.

11 Frankel, The Making of Foreign Policy, p. 111.

12 Millar, "On Writing About Foreign Policy," p. 61.

13 Theodore J. Lowi, "Making Democracy safe for the World: National Politics and Foreign Policy," in Domestic Sources of Foreign Policy, ed. James N. Rossenau (New York: Free Press, 1967), pp. 300-301.

${ }^{14}$ Derek Heater, ed. Contemporary political Ideas, (London: Longman, 1974), p. 27. 
${ }^{15}$ D. Ross Gandy, Marx and History. From Primitive Society to Communist Future, (Austin: University of Texas Press, 1979), p. 141 .

16 H.M. Drucker, The Political Uses of Ideology, (New York: Harper \& Row Publishers, Inc., 1974), p. 99.

17 John Plamenatz, Ideology, (New York: Praeger, 1970), pp. 23-24 .

18 Karl Mannhein, Ideology and Utopia, (New York: Harcourt, Brace and Company, 1936), p. 49.

${ }^{19}$ Ibid., p. 238 .

20 Robert D. Putnam, The Belief of Politicians, (London: Yale University Press, 1973), p. 32.

${ }^{21}$ Giovanni Sartori, "Politics, Ideology, and Belief Systems," American Political Science Review, 63 (1969):400.

22 London, The Making of Foreign Policy, p. 10.

23 Morgenthau, politics Among Nations, p. 83.

24 Ibid., p. 84

${ }^{25}$ Steven Ellner, "Populism in Venezuela, 1935-48: Betancourt and the Acción Democrática," in Latin American Populism in Comparative Perspective, ed. Michael L. Conniff (Albuquerque: University of New Mexico Press, 1982), pp. $137-147$.

${ }^{26}$ Martin C. Needler, Latin American Politics in Perspective, (Ottawa: D. Van Nostrand Company, Inc., 1963), p. 98 .

${ }^{27}$ Louis Wasserman, Handbook of Political "ISMS", (New York: Books for Libraries Press, 1970), p. 98.

$28_{\text {Edward J. Williams, Latin American Christian }}$ Democratic Parties, (Knoxville: The University of Tennessee Press, 1967), p. 43.

29 Ibid., p. 48.

${ }^{30}$ Eduardo Frei Montalva, "The Aims of Christian Democracy," Commonweal, LXXXI, 9 October 1964, pp. 115-116. 
${ }^{31}$ Rafael Caldera, Ideario, La Democrácia Cristiana en América Latina, (Barcelona: Ediciones Ariel, 1970), pp. 193195.

32 Ibid., p. 181 .

33 Roger Tooze, "I.P.E.-What is it?" in The Theory and Practice of International Relations, ed. William Clinton Olson (New Jersey: Prentice-Hall, Inc., 1987), p. 33.

${ }^{34}$ David $\mathrm{H}$. Blakee and Robert $\mathrm{S}$. Walters, The Politics of Global Economic Relations, (New Jersey: Prentice-Hall, Inc., 1987), p. 231 .

35 Theotonio Dos Santos, "The Structure of Dependence," American Economic Association, 43(1970):231.

${ }^{36}$ Arturo Uslar Pietri, De Una a otra Venezuela, (Caracas: Monte Avíla Editores, 1972), p. 21.

${ }^{37}$ David Eugene Blank, Venezuela, politics in a Petroleum Republic, (New York: Praeger, 1984), p. 2 .

${ }^{38}$ Franklin Tugwell, "Petroleum Policy and the Political Process," in Venezuela, The Democratic Experience, ed. John D. Martz and David J. Myers (New York: Praeger, 1977), p. 237 .

${ }^{39}$ Sheldon B. Liss, Diplomacy and Dependency: Venezuela, The United States, and The Americas, (Salisbury: Documentary Publications, 1978), p. 265.

${ }^{40}$ Charles D. Ameringer, "The Foreign Policy of Verezuelan Democracy," in Venezuela, The Democratic Experience, p. 354, 1977.

$41_{\text {Robert D. Bond, ed. Contemporary Venezuela and Its }}$ Role in International Affairs, (New York: New York University Press, 1977), p. 12 .

Chapter Two

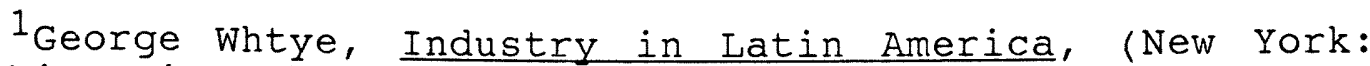
Columbia University Press, 1946), p. 145.

2 John V. Lombardi, Venezuela: The Search for order, The Dream of Progress, (Oxford: Oxford University Press, 1982), p. 216 . 
${ }^{3}$ Paul S. Holbo, "Cold War Drift in Latin America," Current History, 44 (February 1963):67.

${ }^{4}$ Harold Eugene Davis and Larman C. Wilson, ed., Latin American Foreign Policies, (Baltimore: The John Hopkins University Press, 1975), p. 199.

5 Romulo Betancourt, Venezuela: Oil and Politics, (Boston: Houghton Mifflin Company, 1978), p. 242.

${ }^{6}$ Harry Kantor, "The Development of a Democratic Venezuela," Vital Speeches of the Day, 26 (December 1959): 102 .

7 Judith Ewell, Venezuela A Century of Change, (Stanford: Stanford University Press, 1984), p. 126.

8 Ibid.

${ }^{9}$ Robert J. Alexander, "Political Experiment in Venezuela," Current History, 48-49 (December 1965): 341, 367 .

${ }^{10}$ Romulo Betancourt, La Revolución Democrática en Venezuela, (Caracas: Imprenta Nacional, 1968), Vol. III, p. 364 .

11 In Venezuela: Oil and Politics, Betancourt points out that after the Pérez Jimenez's dictatorship took over Communist labor leaders got along well with the military regime whereas $A D$ labor unions were subject to persecution, p. 275 .

12 Romulo Betancourt, La Revolución Democrática en Venezuela, Vol. III, p. 363, claims that Venezuela was one of the Latin American republics to contribute with the United States in the quarantine imposed against Castro's Cuba during the Missiles Crisis.

13 Enrique A. Baloyra, "Oil Policies and Budgets in Venezuela, 1938-1968," Latin American Research Review 9 (1974): 49 .

${ }^{14}$ Carlos Capriles Ayala, Pérez Jimenez y Su Tiempo, (Caracas: Editorial Dusa, 1986), Tomo II, p. 151.

${ }^{15}$ Daniel Hellinger, "Populism and Nationalism in Venezuela," Latin American Perspectives 11 (1984): 43. 
16 Robert J. Alexander, The Venezuelan Democratic Revolution, (New Jersey: Rutgers University Press, 1964), p.

17Ellner, "Populism in Venezuela, 1935-48: Betancourt and the Acción Democrática," p. 142.

18 Fernando H. Cardoso and Enzo Faletto, Depenciencia y Desarollo en América Latina, (Mexico: Siglo Ventiuno Editores, 1969), p. 104 .

${ }^{19}$ Ibid., p. 29

20 Ibid., p. 149 .

21 The Commonweal, 77 (8 March 1963), p. 608.

22 Samuel Shapiro, "Betancourt's Venezuela, Alternative to Castroism?" Commentary 31 (June 1961): 479.

23 Alfredo Tarre Murzi, Los Adecos en el Poder, (Caracas: Publicaciones Seleven, 1983), p. 228.

24 Baloyra, Oil Policies and Budgets in Venezuela, 1938$1968, "$ p. 50.

${ }^{25}$ C.A. Hauberg, "Venezuela Under Betancourt," Current History 40 (April 1961): 237.

26 Robert F. Aide, Latin America, The Politics of Immobility, (New Jersey: Prentice-Hall, Inc., 1974), p. 3.

${ }^{27}$ Shapiro, "Betancourt's Venezuela, Alternative to Castroism?" p. 480. Also see U.S. Dept. of State, U.S. and Venezuela take firm stand against Communist Threats, p. 445.

${ }^{28}$ Loring Allen, Venezuelan Economic Development, (Greenwich: JAI Press, 1977), Vol. 7, p. 67. p. 44 .

${ }^{29}$ Hellinger, "Populism and Nationalism in Venezuela,"

30 Alexander, The Venezuelan Democratic Revolution, pp. $22-23$.

${ }^{31}$ William Clinton olson, The Theory and Practice of International Relations, (New Jersey: Prentice-Hall, Inc., 1987), p. 26 . 
32 Betancourt, La Revolución Democrática en Venezuela, Vol. II, p. 203.

${ }^{33}$ Kalman H. Silvert, The Conflict Society. Reaction and Revolution in Latin America, (New York: American Universities Field Staff, Inc., 1967), p. 231.

34 José A. Silva Michelena, The Illusion of Democracy in Dependent Nations, (Massachusetts: The Massachusetts Institute of Technology Press, 1971), p. 278.

17 .

${ }^{35}$ Aide, Latin America. The Politics of Immobility, p.

${ }^{36}$ Shapiro, "Betancourt's Venezuela, Alternative to Castroism?" p. 480 .

${ }^{37}$ Betancourt, La Revolución Democrática en Venezuela, Vol. II, p. 203.

${ }^{38}$ Silva Michelena, The Illusion of Democracy in Dependent Nations, p. 279.

${ }^{39}$ John D. Martz and David J. Myers, "The Politics of Economic Development," in Venezuela. The Democratic Experience, ed. John D. Martz and David J. Myers (New York: Praeger, 1986), p. 72 .

${ }^{40}$ Carlos A. Romero, La Actuación Electoral de los Empresarios Venezolanos, (Caracas: Instituto Venezolano de Estudios Sociales y Politicos, 1987), p. 7.

$41_{\text {John }}$ D. Martz and David J. Myers, "The Politics of Economic Development," p. 75.

42 For a concise presentation on Venezuelan populism SEE Steven Ellner's "Populism in Venezuela, 1935-48: Betancourt and the Acción Democrática," in Latin American Populism in Comparative Perspective, ed. Michael L. Conniff (Albuquerque: University of New Mexico Press, 1982).

43 Betancourt, La Revolución Democrática en Venezuela, Vol I, p. 479 .

44 Ibid.

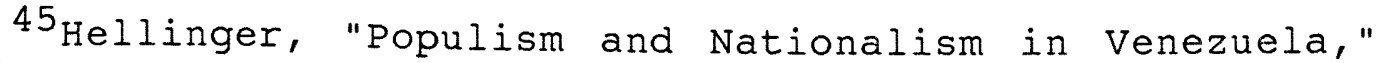
p. 52 . 


\section{Chapter Three}

${ }^{1}$ Rafael Caldera, La Solidaridad Pluralista de América Latina, (Caracas: Oficina Central de Información, 1973), pp. 191-194. Also See U.S. Area Handbook for Venezuela, p. 212.

2 Eduardo Frei Montalva, "The Aims of Christian Democracy," Commonweal LXXXI (October 9, 1964), p. 66.

3 Rafael Caldera, Ideario. La Democracia Cristiana en Anérica Latina, (Barcelona: Ediciones Ariel, 1970), p. 190.

${ }^{4}$ Charles D. Ameringer, "The Foreign Policy of Venezuelan Democracy," in Venezuela. The Democratic Experience, p. 348 .

${ }^{5}$ George W. Grayson, "Venezuela's Presidential Politics," Current History, 66-67 (January 1974): 39.

б Ameringer, "The Foreign Policy of Venezuelan Democracy," p. 348 .

${ }^{7}$ John D. Martz and David J. Myers, "The Politics of Economic Development," in Venezuela. The Denocratic Experience, p. 77 (rev. ed.).

8 "President Nixon Meets With President Caldera of Venezuela," Department of State Bulletin, LXII, June 29, 1970, p. 798.

${ }^{9}$ Judith Ewell, "The Development of Venezuelan Geopolitical Analysis Since World War II," Journal of Interamerican Studies and World Affairs, 24 (1982): 315.

10 John D. Martz, "Venezuelan Foreign Policy Toward Latin America," in Contemporary Venezuela and Its Role in International Affairs, ed. Robert D. Bond (New York: New York University Press, 1977), p. 175.

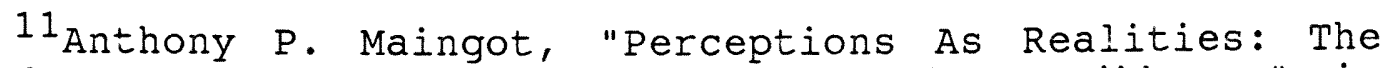
United States, Venezuela and Cuba in the Caribbean," in Latin American Nations in World Politics, ed. Heraldo Muñoz and Joseph S. Tulchin (Boulder, Colorado: Westview Press, $1984)$, p. 73 .

12 The New York Times, April 22, 1973, p. 17.

13 Martz, "Venezuelan Foreign Policy Toward Latin America," p. 176. 
${ }^{14}$ Grayson, "Venezuela's Presidential Politics," p. 27.

${ }^{15}$ Robert D. Bond, "Venezuela, La Cuenca Del Caribe y la Crisis Centroamericana," Foro Internacional 22 (OctoberDecember 1981): 170 .

16 Ibid.

17Martz, "Venezuelan Foreign Policy Toward Latin America," p. 175.

18 Ana T. Romero, "Venezuela's Initiatives in the Caricom Region 1973-1978: Impact and Implications," (Master Thesis, University of West Indies, 1980), p. 42.

19 Robert D. Bond, "Venezuela's Role in International Affairs," in Contemporary Venezuela and Its Role in International Affairs, p. 251.

20 Martz, "Venezuelan Foreign Policy Toward Latin America," p. 181.

$21_{\text {Business Week, March 11, 1972, p. } 50 .}$

22 Theotonio Dos Santos, "The Structure of Dependence," American Economic Association 43 (1970): 171.

23 Judith Ewell, Venezuela A Century of Change, p. 169.

${ }^{24}$ Dos Santos, "The Structure of Dependence," p. 168.

${ }^{25}$ Charles D. Ameringer, "The Foreign Policy of Democratic Venezuela," in Venezuela, The Democratic Experience, p. 417 (rev. ed.)

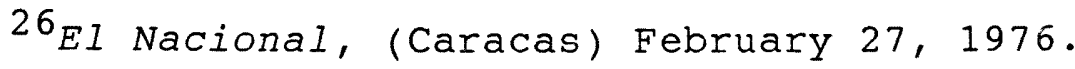

27 El Nacional, (Caracas) February 22, 1976.

${ }^{28}$ Caldera, La Solidaridad pluralista de América Latina, p. 123 .

29 Donald L. Herman, "Ideology, Economic Power and Regional Imperialism," Caribbean Studies 18 (1979): 63 .

30 John D. Martz, "Venezuelan Foreign Policy and the Role of Political Parties," in Latin American Nations in World Politics, p. 143. 
${ }^{31}$ Sheldon B. Liss, "Venezuela," in Latin American Foreign Policies, ed. Harold E. Davis and Larman C. Wilson (Baltimore: The John Hopkins University Press, 1975), p. 436 .

Chapter Four

${ }^{1}$ Martz, "Venezuelan Foreign Policy and the Role of. Political Parties," p. 142.

2 Morgenthau, Politics Among Nations, p. 5 .

3 Ibid., p. 26.

${ }^{4}$ Cardoso y Faletto, Dependencia y Desarollo en América Latira, p. 104 .

${ }^{5}$ Dos Santos, "The Structure of Dependence," p. 231. See also Alberto van Klaveren, "The Analysis of Latin American Foreign Policies: Theoretical Perspectives," in Latin American Nations in World Politics, ed. H. Muñoz and J. Tuichin, p. 9 .

${ }^{6}$ Morgenthau, Politics Among Nations, p. 143.

7 Reynolds, An Introduction to International Relations, p. 51. Also see Kurt London, The Making of Foreign Policy, East and West, p. 54.

${ }^{8}$ Blake and Walters, The Politics of Global Economic Relations, p. 231.

${ }^{9}$ Liss, Diplomacy and Dependency, p. 265.

10 Tugwell, "Petroleum Policy and the political Process," p. 237.

${ }^{11}$ Rosenau, Domestic Sources of Foreign Policy, pp. 3-4.

12 London, The Making of Foreign Policy, p. 20.

13 Millar, "On Writing About Foreign Policy," p. 61.

${ }^{14}$ Lowi, "Making Democracy Safe for the World: National Politics and Foreign Policy," pp. 300-301.

${ }^{15}$ Frankel, The Making of Foreign Policy, p. 111.

${ }^{16}$ London, The Making of Foreign Policy, p. 10. 
${ }^{17}$ Morgenthau, Politics Among Nations, p. 83. ${ }^{18}$ Gandy, Marx and History, p. 141. 


\section{BIBLIOGRAPHY}

A. Official publications

Blutstein, Howard I. and Edwards, David J. Area Handbook for Venezuela. Washington, D.C: U.S. Government Printing Office, 1977.

Caldera, Rafael. Solidaridad Pluralista de América Latina. Caracas: Oficina Central de Información, 1973 .

Oficina Central de Información. Seis Años de Agresión. Caracas: Imprenta Nacional, 1967.

United States, Department of State. U.S. and Venezuela Take Firm Stand Against Communist Threats. Washington: Government Printing Office, March 1963.

United States, Department of State. President Nixon Meets With President Caldera of Venezuela. Washington: Government Printing Office, June 1970.

B. Documented speeches

1. "Address by the President of Venezuela, Romulo Betancourt, at a press conference celebrated at the house of the Governor of the state of New York, Nelson Rockefeller, in Tarrytown, 22 February 1963." La Revolución Democrática en Venezuela. Caracas: Imprenta Nacional, 1968, Vol. III, Pp. 260-264.

2. "Speech by the President of the United States, John F. Kennedy, during his two-day visit to Venezuela on December 16, 1961." La Revolución Democrática en Venezuela. Vol. II, pp. 202-203.

3. "Speech by President Betancourt at the inauguration of the second Meeting of the Conference of the Organization of Petroleum Exporting Countries (OPEC), held in Caracas, January 16, 1961." La Revolución Democrática en Venezuela. Vol. I, pp. 476-479. 
4. "Address by President Caldera before the U.S. Congress." Washington: U.S. Department of State Bulletin, 1970, pp. 796-799.

C. Articles and Periodicals

Alexander, Robert J. "Political Experiment in Venezuela." Current History 48-49 (December 1965).

Ameringer, Charles D. "The Foreign Policy of Venezuelan Democracy." In Venezuela, The Democratic Experience. Ed. John D. Martz and David J. Myers. New York: Praeger, 1977.

Baloyra, Enrique A. "Oil Policies and Budgets in Venezuela, 1938-1968." Latin American Research Review 9 (1974).

Beatty, Donald W. "Venezuela: A New Era." Current History 38 (March 1960).

Blank, David Eugene. "Oil and Democracy in Venezuela." Current History 78 (February 1980).

Bond, Robert D. "Venezuela, La Cuenca Del Caribe y la Crisis Centroamericana." Foro Internacional 22 (October-December 1981).

Bond, Robert D. "Venezuela's Role in International Affairs." In Contemporary Venezuela and Its Role in International Affairs. Ed. Robert D. Bond. New York: New York University Press, 1977.

Dos Santos, Theotonio. "The Structure of Dependence." American Economic Association 43 (1970).

Ellner, Steven. "Populism in Venezuela, 1935-48: Betancourt and the Acción Democrática." In Latin American Populism in Comparative Perspective. Ed. Michael L. Conniff. Albuquerque: University of New Mexico Press, 1982.

Ewell, Judith. "The Development of Venezuelan Geopolitical Analysis Since World War II." Journal of Inter-American Studies and World Affairs 24 (1982). 
Ferris, Elizabeth G. "The Andean Pact and the Amazon Treaty. Reflections of Changing Latin American Relations." Journal of Interamerican Studies and World Affairs 23 (May 1981).

Frei Montalva, Eduardo. "The Aims of Christian Democracy." Commonweal LXXXI (October 1964).

Friedenberg, Daniel M. "Can the Alliance for Progress Work?" Commentary 34 (August 1962).

Grayson, George W. "Venezuela's Presidential Politics." Current History 66-67 (January 1974).

Hauberg, C.A. "Venezuela Under Betancourt." Current History 40 (April 1961).

Hellinger, Daniel. "Populism and Nationalism in Venezuela." Latin American Perspectives 11 (1984).

Herman, Donald L. "Ideology, Economic Power and Regional Imperialism." Caribbean Studies 18 (1979).

Herz, John H. "The Territorial State Revisted: Reflections on the Future of the Nation State." In International Politics and Foreign Policy. Ed. James N. Rosenau. New York: The Free Press, 1969.

Holbo, Paul S. "Cold War Drift in Latin America." Current History 44 (February 1963).

Kantor, Harry. "The Development of a Democratic Venezuela." Vital Speeches of the Day 26 (December 1959).

Liss, Sheldon B. "Venezuela." In Latin American Foreign policies. Ed. Harold Eugene Davis and Larman C. Wilson. Baltimore: The John Hopkins University Press, 1975.

Lowi, Theodore. "Making Democracy Safe for the World: National Politics and Foreign Policy." In Domestic Sources of Foreign Policy. Ed James $N$. Rosenau. New York: Free Press, 1967. 
Maingot, Anthony P. "Perceptions As Realities: The United States, Venezuela and Cuba in the Caribbean." In Latin American Nations in World Politics. Ed. Heraldo Muñoz and Joseph S. Tulchin. Boulder, Colorado: Westview Press, 1984.

Martz, John D. "Venezuelan Foreign Policy Toward Latin America." In Contemporary Venezuela and Its Role in International Affairs, 1977.

Martz, John D. "Venezuelan Foreign Policy and the Role of Political Parties." In Latin American Nations in World Politics, 1984.

Martz, John D. and Myers, David J. "The Politics of Economic Development." In Venezuela, The Democratic Experience, 1986.

Millar, T.B. "On Writing About Foreign Policy." In International Politics and Foreign Policy, 1969.

Sartori, Giovanni. "Politics, Ideology, and Belief Systems." American Political Science Review 63 (1969).

Schuyler, George W. "Venezuelan Progress Reconsidered." Current History 60 (February 1971).

Shapiro, Samuel. "Betancourt's Venezuela, Alternative to Castroism?" Commentary 31 (June 1961).

Taylor, Philip B. "Progress in Venezuela." Current History 52-53 (November 1967).

Tooze, Roger. "I.P.E.-What is it?" In The Theory and Practice of International Relations. Ed. William C. Olson. New Jersey: Prentice-Hall, Inc., 1987.

Tugwell, Franklin. "Petroleum Policy and the Political Process." In Venezuela, The Democratic Experience, 1977 .

D. Books

Aide, Robert F. Latin America. The Politics of Immobility. New Jersey: Prentice-Hall, Inc., 1974. 
Alexander, Robert J. The Venezuelan Democratic Revolution. New Jersey: Rutgers University Press, 1964 .

Betancourt, Romulo. La Revolución Democrática en Venezuela. Caracas: Imprenta Nacional, 1968. Four Volumes.

Venezuela: Oil and Politics. Boston: Houghton Mifflin Company, 1978.

Blake, David H. and Walter, Robert S. The Politics of Global Economic Relations. New Jersey: PrenticeHall, Inc., 1987.

Blank, David E. Venezuela, Politics in a Petroleum Republic. New York: Praeger, 1984.

Boersner, Demetrio. Venezuela y El Caribe: Presencia Cambiante. Caracas: Monte Avila Editores C.A., 1976 .

Bond, Robert D. Ed. Contemporary Venezuela and Its Role in International Affairs. New York: New York University Press, 1977.

Caldera, Rafael. Ideario. La Democracia Cristiana en América Latina. Barcelona: Ediciones Ariel, 1970.

- International Social Justice and Latin American Nationalism. Caracas: Editorial Arte, 1974.

Capriles Ayala, Carlos. Pérez Jimenez y su Tiempo. Caracas: Editorial Dusa C.A., 1986.

Cardoso, Fernando H. and Faletto, Enzo. Dependencia y Desarrollo en América Latina. Mexico: Siglo Ventiuno Editores S.A., 1969.

Conniff, Michael L. ED. Latin American Populism in Comparative Perspective. Albuquerque: University of New Mexico Press, 1982.

Davis, Harold E. and Wilson, Larman C. Ed. Latin American Foreign Policies. Baltimore The Johns Hopkins University Press, 1975.

Drucker, H.M. The Political Uses of Ideology. New York: Harper \& Row Publishers, Inc., 1974. 
Ewell, Judith. Venezuela A Century of Change. Stanford: Stanford University Press, 1984.

Frankel, Joseph. The Making of Foreign Policy. London: Oxford University Press, 1963.

Gandy, Ross D. Marx and History. From Primitive Society to Communist Future. Austin: University of Texas Press, 1979 .

Heater, Derek. Ed. Contemporary Political Ideas. London: Longman, 1974.

Liss, Sheldon B. Diplomacy and Dependency: Venezuela, The United States and the Americas. Salisbury: Documentary Publications, 1978.

Lombardi, John V. Venezuela: The Search for order, The Dream of Progress. Oxford: Oxford University Press, 1982 .

London, Kurt. The Making of Foreign Policy, East and West. New York: J.B. Lippincott Company, 1965.

Mannhein, Karl. Ideology and Utopia. New York: Harcourt, Brace and Company, 1936.

Martz, John D. and Myers, David J. Eds. Venezuela. The Democratic Experience. New York: Praeger, 1986.

Morgenthau, Hans J. Politics Among Nations. New York: Alfred A. Knopf, Inc., 1967.

Muñoz, Heraldo and Tulchin, Joseph F. Eds. Latin American Nations in World Politics. Boulder, Colorado: Westview Press, 1984.

Needler, Martin C. Latin American Politics in Perspective. Ottawa: D. Van Nostrand Company, Inc., 1963.

Olson, William C. Ed. The Theory and Practice of International Relations. New Jersey: PrenticeHall, Inc., 1987.

Pearson, Lester. Democracy in World Politics. New York: Oxford University Press, 1956.

Plamenatz, John. Ideology. New York: Praeger, 1970. 
Putnam, Robert D. The Beliefs of Politicians. London: Yale University Press, 1973.

Reynolds, P.A. An Introduction to International Relations. New York: Longman, Inc., 1980.

Romero, Carlos A. La Actuación Electoral de los Empresarios Venezolanos. Caracas: Instituto Venezolano de Estudios Sociales y Politicos, 1987.

Romero, Ana T. "Venezuela's Initiatives in the Caricom Region 1973-1978: Impact and Implications." Master Thesis, University of West Indies, 1980.

Rosenau, James N. Ed. Domestic Sources of Foreign Policy. New York: Free Press, 1967.

- Ed. International Politics and Foreign Policy. New York: Free Press, 1969.

Silva Michelena, José A. The Illusion of Democracy in Dependent Nations. Massachusetts: The Massachusetts Institute of Technology Press, 1971.

Silvert, Kalman $\mathrm{H}$. The Conflict Society. Reaction and Revolution in Latin America. New York: American Universities Field Staff, Inc., 1967.

Tarre Murzi, Alfredo. Los Adecos en el Poder. Caracas: Publicaciones Seleven, 1983.

Uslar Pietri, Arturo. De Una a Otra Venezuela. Caracas: Monte Avila Editores, 1972.

Wasserman, Louis. Handbook of Political "ISMS." New York: Books for Libraries Press, 1970.

William, Edward J. Latin American Christian Democratic Parties. Knoxville: The University of Tennessee Press, 1967.

Wythe, George. Industry in Latin America. New York: Columbia University Press, 1946. 
VITA

Title of Thesis:

AN ANALYSIS OF VENEZUELA'S FOREIGN POLICY DURING THE PERIOD OF THE BETANCOURT DOCTRINE AND CALDERA'S IDEOLOGICAL

$$
\text { PLURALISM. }
$$

Name: $\quad$ Franklin Acosta

Born: July 21, 1957, Venezuela

Married, Venezuelan Citizen

Education:

1964-1970 Elementary School, Venezuela

1971-1976 High School, Venezuela

Arrived in the United States in January 1980 for Educational Purposes.

1980-1981 University of Miami Intensive English Program.

1981-1982 Associate in Arts, Miami-Dade Community College.

1982-1984 Bachelor of Arts in International Relations and Certificate in Latin American and Caribbean Studies, Florida International University.

Major Department: International Studies 